\title{
SAĞLIK HİZMETLERİ MESLEK YÜKSEKOKULU ÖĞRENCİLERİNİN YAZMA KAYGILARI VE ÖZ-YETERLİK ALGILARININ ÇEŞITLII DEĞİŞKENLER AÇISINDAN İNCELENMESI
}

\begin{abstract}
Öğr. Gör. Ebrar ILIMAN
Sivas Cumhuriyet Üniversitesi, ebrar@ cumhuriyet.edu.tr, ORCID:0000-0002-5255-8482

Öğr. Gör. Aysel ARSLAN

Sivas Cumhuriyet Üniversitesi, arslanaysel.58@gmail.com, ORCID: 0000-0002-8775-1119

Öğr. Gör. Rukiye ASLAN

Sivas Cumhuriyet Üniversitesi, raslan@ cumhuriyet.edu.tr, ORCID:0000-0001-5843-626X

\section{$\ddot{O} Z$}

Bu çalışmada; Sağllk Hizmetleri Meslek Yüksekokulu (SHMYO) öğrencilerinin yazma kaygıları ve özyeterliklerinin cinsiyet, sinıf, ögretim türü, gelir düzeyi, ikamet yeri, mezun olunan lise türü ve eğitim alınan branş değişkenleri açısından anlaml farklllık gösterip göstermediğinin belirlenmesi amaçlanmaktadır. Araştırmada betimsel tarama modeli kullanılmıştır. Araştırmanın örneklem grubunu 2018-2019 eğitim-öğretim yılı bahar döneminde Sivas Cumhuriyet Üniversitesi SHMYO'da eğitim görmekte olan 340 klz, 115 erkek olmak üzere 455 ögrenci oluşturmaktadır. Ögrencilerin yazma kaygılarını belirlemek için Karakaya ve Ülper (2011) tarafindan gelişstirilen tek boyut ve 35 madden oluşan "Yazma Kaygısı Ölçeği" kullanılmıştır. Ölçeğin güvenirliği .97, bu çalışmada ise .97 olarak bulunmuştur. Öğrencilerin öz-yeterlik algllarını belirlemek içinse Sherer, Maddux, Mercandante, Dunn, Jacobs ve Rogers (1982 tarafindan geliştirilen Türkçeye uyarlaması Yıldirım ve Illhan (2010) tarafindan yapılan "Genel Öz-yeterlik Ölçeğì" kullanılmıştır. Ölç̧ek, başlama, yılmama ve sürdürme çabası-lsrar olmak üzere üç alt boyuttan ve toplamda 17 maddeden oluşmaktadır. Uyarlanan ölçeğin güvenirliği .80, bu çalışmada ise .70 olarak bulunmuştur. Araştırma verilerinin analizinde; Kolmogorov-Smirnov (K-S), Aritmetik Ortalama, Standart Sapma, Bağımsız T Testi, Anova, LSD, Pearson Korelasyon Katsaylsı kullanilmiştır. Öğrencilerin öz-yeterlik algıları cinsiyet, gelir düzeyi, branş; yazma kaygıları ise ilamet yeri, gelir düzeyi ve branş değiskenlerine göre anlaml farkllllk gösterdiği; öz-yeterlik ve yazma kaygllarl arasinda orta düzeyde negatif yönde (-.34) bir ilişki olduğu belirlenmiştir.
\end{abstract}

Anahtar Kelimeler: Yazma kaygısı, kaygl, üniversite, öğrenci

\section{EXAMINING HEALTH SERVICES VOCATIONAL SCHOOL STUDENTS' WRITING ANXIETY AND SELF-SUFFICIENCY PERCEPTIONS WITH REGARD TO VARIOUS VARIABLES}

\begin{abstract}
The purpose of this study is to determine whether there is a significant difference in the writing anxiety and selfsufficiency of the Vocational School of Health Services students in terms of gender, class, type of education, income level, place of residence, type of graduated high school, and branch of education. The sample of the research involved 835 students in total, comprising 340 female and 115 male students, studying at Health Services Vocational School of Sivas Cumhuriyet University in the spring period of 2018-2019 education-training year. Writing anxiety scale, which consists of 35 items and one dimension, and developed by Karakaya and Ulper (2011), was used for the data collection. The reliability coefficient of the scale was found as .97 in both the original scale development study (Karakaya and Ulper, 2011), and in this study. In order to determine the self-sufficiencies of the students, the "General Self-Sufficiency Scale" developed by Sherer, Maddux, Mercandante, Dunn, Jacobs and Rogers (1982) and adopted to Turkish by Ylldirtm and Illhan (2010), was used. The scale comprises three sub-dimensions, namely quitting and insistence, and a total of 17 items. The total reliability score of the adapted scale was found as .80, and in this study it was found as .70. The Kolmogorov-Smirnov (K-S) test, Mean, Standard Deviation, Independent Sample T Test, Anova, LSD, and Pearson Correlation Coefficient were used for the data analyses. It was concluded that the self-sufficiencies of the students were statistically significantly different by the
\end{abstract}




\section{ULUSLARARASI INTERNATIONAL \\ TÜRK EĞiTiM BíLIMLERI DERGISi JOURNAL OF TURKISH EDUCATION SCIENCES \\ UTEB Y11 / Year: 7 | Sayı / Issue: 12 | Nisan / April 2019 \\ ISSN 2148-2314 $\mid$ uteb.gop.edu.tr}

income level, gender and branch variables; the writing anxiety of the students were statistically significantly different by the place of residence, income level and branch variables. Besides, it was determined that total score correlations of the writing anxiety and self-sufficiencies of the students were at medium level in negative direction $(-.34)$.

Key Words: Writing anxiety, anxiety, university, student

\section{GİRIŞ}

Birey, çevresiyle iletişim kurabilmek için dinleme, konuşma, okuma ve yazma olmak üzere dört temel kategoride değerlendirilen dil becerilerini kullanmaktadır. Bu becerilerden dinleme ve okuma anlama, konuşma ve yazma ise anlatma becerileri olarak ifade edilmektedir. Yazma becerisi birey ve toplumların her türlü bilgi birikimlerinin nesilden nesile aktarılmasında oldukça büyük önem taşımaktadır. Yazma sürecinde birey toplum tarafından üzerinde anlaşılan ortak kod, sistem ve semboller kullanarak duygu, düşünce, dilek, olay vb. her türlü bilgiyi belirli bir bütünlük gösterecek şekilde düzenleyerek ifade etmektedir (Özbay, 2007; Göçer, 2010). Yazma becerisi; farklı boyutları olan, farklı alt becerilerin birlikte kullanılmasını gerektiren, dil becerileri arasındaki en karmaşık beceri şeklinde tanımlanmaktadır (Espin, Weissenburger ve Benson, 2004: 55). Yazma sürecinde; yazma kurallarına uygun ve anlamlı bir bütünlüğe sahip bir metin oluşturulması (Çeçen, 2011; Keçik ve Subaşı Uzun, 2004: 64), zihinde yapılandırılmış bilgilerin aktarılması (Güneş, 2007), birçok zihinsel aktivitenin aynı anda yürütülmesi (Alamargot ve Chanquoy, 2001), farklı fiziksel becerilerin birlikte kullanılması zorunluluğu bulunmaktadır (Coşkun, 2007). Bireyin yazdığı yazıda; yazma amacını, yazının konusunu, ortaya koyduğu ana ve yan düşünceleri, gerekli yerlerde dil sanatlarını, dilin işaret ve simgelerini doğru şekilde kullanarak ortaya koyması (Alamargot ve Chanquoy, 2001), bilinçli bir çaba göstererek çözümleyici bir aktivite gerçekleştirmesi gerekmektedir (Vygotsky, 2018: 145-146). Tüm bu gerekliliklerden dolayı yazma becerisinin, öğrencilerin edinmekte ve geliştirmekte en çok zorlandıkları dil becerisi olduğu ifade edilmektedir (Gögüuss, 1978; Maltepe, 2006). Bireyin yazma becerisi geliştikçe her türlü bilgi ve düşünceyi planlı bir şekilde daha kolay bir şekilde transfer edebileceği belirtilmektedir (Akyol, 2011).

Birey, yazma sürecinde duygu ve düşüncelerini aktarmakta farklı psikolojik etkiler nedeniyle sorunlar yaşayabilmektedir (Zorbaz, 2010: 17). Yazmaya ilişkin yaşadığı bu problemler bireyin yazmaya yönelik istekliliğini azaltmaktadır. Yaşanılan bu sorunlar yazmaya yönelik kaygı durumu olarak ifade edilmektedir (Ateş ve Akaydın, 2015: 26). Kayg1; tam olarak sorunun ne olduğunun bilinmemesine rağmen hissedilen ve bireyi olumsuz şekilde etkileyen korku olarak tanımlanmaktadır (Morgan, 1998: 228). Bireyin hissettiği kayg1; üzüntü, korku, başaramayacağı inancı, acziyet, belirsizlikten korkma, önyarg1, yargılanma endişesi vb. duyguları içermektedir. Kaygı durumuna neden olan sorun çözülemezse yaşanılan kaygının şiddeti artmakta ve kaygı süreklilik kazanmaktadır (Cüceloğlu, 2013). Yazma kaygısı bireyin yazmaya ilişkin geliştirdiği, farklı etkenler sonucu oluşabilen olumsuz tepki (Petzel ve Wenzel, 1993); bireyin yazma sürecinde başarısız olma düşüncesiyle hissettiği psikolojik gerginlik olarak ifade edilmektedir. Yazma kaygisı hisseden birey, yazma eylemini rahatsız edici, korkutucu ve kendilerine yönelik bir ceza şeklinde algılamaktadır (Teichman ve Poris, 1989; Zorbaz, 2010: 194). Birey yazmak zorunda olduğu durumda aşırı şekilde gergin olmakta, yazmaktan kaçınmakta (Zorbaz, 2011: 2272), yazma eylemini sürecin herhangi bir aşamasında bırakabilmektedir (McLeod, 1987: 427). Bireyin yazmaya yönelik hissettiği kaygı durumu fizyolojik ve psikolojik olarak görülmektedir. Psikolojik etkiler endişe, korku, heyecan vb. durumları; fizyolojik etkiler midede kasılma veya boşluk hissi, terleme, titreme, baş ağrısı vb. durumları içermektedir (Petzel ve Wenzel, 1993; Poff, 2004: 168). Yazmaya yönelik kayg1 yaşayan bireyin aklına yazmak zorunda olduğu zamanlarda ilgili ilgisiz pek çok farklı iş 


\section{ULUSLARARASI INTERNATIONAL \\ TÜRK EĞiTiM BILIMLERI DERGISi JOURNAL OF TURKISH EDUCATION SCIENCES \\ UTEB Yıl / Year: 7 | Sayı / Issue: 12 | Nisan / April 2019 \\ ISSN 2148-2314 $\mid$ uteb.gop.edu.tr}

gelmektedir. Bireyin yaşadığı bu olumsuz durumu aşabilmesi için yazma sürecine başlamadan önce kendini psikolojik olarak sürece yönelik hazırlaması gerekmektedir (Warburton, 2007).

Tighe (1987: 1), yazma kaygısı yüksek olan bireylerin özgüvenlerinin düşük düzeyde olduğunu belirtmektedir. Bu doğrultuda bireyin kendine ilişkin güveninin ve yeterlik algısının, yaptığ işe yönelik motivasyon düzeyinin yüksek olmasının, yaşadığı kaygı durumuyla baş etmesinde önemli olduğu, birey için süreci kolaylaştıracağ ifade edilmektedir (Arslan, 2017a: 31). Bireyin üstbilişsel stratejileri etkin kullanmasının yaşadığı kaygıyı azaltacağı belirtilmektedir (Melanlıŏlu, 2014: 107). Bu doğrultuda, üstbilişsel stratejiler arasında yer alan öz-yeterlik algısı yüksek olan bireylerin yaşadıkları kaygı durumunu daha kolay aşabilecekleri belirtilmektedir (Arslan, 2017a: 32). Öz-yeterlik algısı Bandura tarafından geliştirilen Sosyal Öğrenme Kuramı içinde yer alan temel kavramlar arasında bulunmaktadır (Derman, 2007). Bandura (1997) öz-yeterliği, bireyin herhangi bir konuda performans sergilerken yapması gerekenlere yönelik olarak kendine ve yapabileceklerine ilişkin düşüncesi olarak açıklamaktadır. Tschannen-Moran ve Woolfolk Hoy (2001) öz-yeterlik algısını, bireyin çözmek zorunda olduğu durumlara ilişkin başaracağına yönelik inancı ve kendisinden beklentileri; Senemoğlu (2005), bireyin kendi hakkındaki yargıs1; Chaplain (2000), bireyin yeteneklerinin farkında olması ve kendisine inanmas1; Bandura (1997), bireyin belli bir duruma ilişkin başarılı olabilmesi için göstermesi gereken performansa yönelik olarak kendi becerilerinin farkında olması, süreci organize etmesine ilişkin farkındalığı olarak tanımlamaktadır. Öz-yeterlik algısı üst düzeyde olan bireyler karşılaştıkları zor durumlarda kaçınmak yerine sorunların üzerine giderek mücadele etmeyi tercih etmektedir (Aşkar ve Umay 2001).

Bireyin hayatında başarabileceğine inanarak belirlediği hedefler bulunmaktadır. Öz-yeterlik algıs1; bireyin belirlediği bu hedefleri gerçekleştirebilmesi ve karşısına çıkabilecek olası engelleri ortadan kaldırmak için ne yapması gerektiği, göstermesi gereken çabanın farkında olması olarak ifade edilmektedir. Bireyin karşılaştığı zorluklarla mücadele etmek için geliştirdiği stratejiler bulunmaktadır. Bireyin geliştirdiği bu stratejileri etkin kullanabilmesi (Pajares ve Schunk, 2001), kendi etkinliklerini düzenlemesi, sahip olduğu becerilerini şekillendirmesi (Karademir, 2013), çevresini denetim altına alması öz-yeterlik algısı ile bağlantılı olarak gerçekleşmektedir (Hazır Bıkmaz, 2004). Üredi ve Üredi (2006), bireyin gösterdiği performansın aslında var olan durumdan değil var olduğuna inandığı durumdan kaynaklandığını, kendine olan inancının performansını olumlu ya da olumsuz etkileyerek motivasyonunu belirlediğini ve dolayısıyla da sonucu etkilediğini ifade etmektedir. Özenoğlu Kiremit (2006) ise öz-yeterliğin bireyin olumlu ya da olumsuz düşünmesini, amaçlarını, yaşam biçimini, zorluklara ilişkin göstereceği çabayı, çabanın sonucunda ortaya çıkacak ürünü belirlediğini söylemektedir.

Bandura (1997) bireyin öz-yeterlik inancının birbiriyle etkileşim halinde olan dört temel kaynağa dayandığını belirtmektedir. Bu kaynakları; performans başarıları, dolaylı yaşantılar, sözel ikna, duyuşsal ve fiziksel durum olarak ifade etmektedir. Performans başarıları, bireyin kendi yaşantısı sonucunda elde ettiği deneyimleri ifade etmektedir. Bireyin daha önce elde ettiği olumlu ya da olumsuz tecrübeler karşılaştıkları problemler karşısındaki öz-yeterlik algılarını belirlemektedir (Akgün, 2008). Bireyin geçmişindeki yaşam deneyimleri onun gelecekteki performansı üzerinde etkili olmaktadır (Bandura, 1977). Öz-yeterlik algısının dayandığ1 kaynaklar arasında yer alan başkalarının yaşadığı deneyimlerde, bireyin bir beceri ya da davranışa yönelik olarak başkalarının yapabileceklerini gözlemleyerek de kendi yeterliğine ilişkin yargılarda bulunabileceği belirtilmektedir (Schunk, 2009). Bu yeterlik algısı olumlu 


\section{ULUSLARARASI INTERNATIONAL \\ TÜRK EĞiTiM BILIMLERI DERGISi JOURNAL OF TURKISH EDUCATION SCIENCES \\ UTEB Yıl / Year: 7 | Sayı / Issue: 12 | Nisan / April 2019 \\ ISSN 2148-2314 $\mid$ uteb.gop.edu.tr}

olabileceği gibi olumsuz da olmaktadır. Bireyin bir konuda daha önce deneyimi olmamışsa ya da olma şansı yoksa başkalarını gözlemleyerek yeterliğine ilişkin karar vermesi oldukça önemli bir kaynak olmaktadır (Bandura, 1997). Kaynak olarak kabul edilen modelin bireysel ve kültürel özelliklerinin uyum derecesi de etki oranını artırmaktadır (Bandura, 1977). Sözel ikna, bireyin herhangi bir konuda gösterdiği çabanın çevresi tarafından sözel olarak desteklenmesi ya da eleştirilmesi olarak tanımlanmaktadır (Bandura, 1997). Birey olumlu destek alırsa gösterdiği çabayı ve davranışı sürdürmekte olumsuz ifadelerde ise bırakabilmektedir. Ancak sözel ikna genellikle tek başına değil diğer kaynaklardan alınan bilgilerle etkili olmaktadır (Akgün, 2008). Bireyin performansını ortaya koyarken içinde bulunduğu duygusal ve fiziksel durum yeterlik algısını olumlu ya da olumsuz olarak etkilemektedir (Bandura, 1997). Bireyin yaşadığı tedirginlik, mutluluk, sevinç, endişe, üzüntü, korku vb. duyuşsal etkenler; hastalık, sakatlık, mekânın etkisi, kendini iyi hissetme vb. fiziksel etkenler bireyin kendi hakkında verdiği başarı ya da başarısızlığa ilişkin beklentilerini etkilemektedir (Schunk, 2009). Zimmerman (1995) duyuşsal ve fiziksel etmenlerin, öz-yeterlik algısı geliştirilirken dikkate alınarak mümkün olduğunca kontrol altın altına alınması gereken unsurlar olduğunu söylemektedir.

Bireyin öz-yeterlik algısının gelişmesi için genellikle uzun bir süreç ve deneyimler gerekmektedir (Bandura, 1986). Öz-yeterlik algısı yüksek olan bireylerin düşük olan bireylere göre daha başarılı performans gösterdikleri belirtilmektedir. Öz-yeterlik kavramı süreç içinde pek çok konuyla bağlantılı olarak araştırılmış öğretmen öz-yeterliği (Akgün, 2013), fen öğretimi öz-yeterliği (Akbaş ve Çelikkaleli, 2006), biyolojik öz-yeterlik (Ekici, 2005), akademik öz-yeterlik (Arslan, 2017a, 2018a), internet öz-yeterliği (Gülmez, 2015) vb. pek çok alana yönelik olarak çalışmalar yapılmıştır. Derman (2007) tarafından yapılan öğretmenlerin öz-yeterlikleri ve mesleki tutumları, Arslan (2017a) tarafından yapılan ortaokul öğrencilerinin okuma kaygıları ve öz-yeterlikleri, Arslan (2018a) tarafından yapılan öğrencilerin konuşma kaygıları ve öz-yeterlikleri, Koç ve Arslan (2017) tarafından yapılan ortaokul öğrencilerinin okuma stratejileri ve öz-yeterlikleri gibi pek araştırmada öz-yeterliğin diğer pek çok beceri ve davranış üzerindeki etkisi belirlenmeye çalışılmıştır. Öz-yeterlik ve yazma kaygısı arasındaki ilişkinin belirlenmesine yönelik olarak alan yazın tarandığında Arslan (2018b) tarafından ortaokul düzeyindeki öğrencilerin öz-yeterlik ve yazma kaygısını belirlemeye yönelik yapılan çalışma; Öztürk ve Saydam (2014) tarafından öğrencilerin yabancı dilde yazma kaygısı ve özyeterlik arasındaki ilişkiyi belirlemeye yönelik yapılan araştırma dışında başka bir çalışmaya rastlanmamıştır. Arslan'ın (2018b) çalışmasında elde edilen bulgulara göre öğrencilerin yazma kaygıları ile öz-yeterlik algıları arasında orta düzeyde bir ilişki; Öztürk ve Saydam (2014) tarafından yapılan çalışmada da öğrencilerin yabancı dilde yazma kaygıları ile öz-yeterlikleri arasında orta düzeyde bir ilişkinin olduğu sonucuna ulaşılmıştır. Bu doğrultuda öğrencilerin daha sonraki eğitim süreçlerinde bu ilişkinin boyutunun belirlenmesi için bu çalışmanın yapılmasına karar verilmiştir. Yapılan bu çalışmanın amacı; SHMYO öğrencilerinin yazma kaygıları ile öz-yeterlikler algılarının çeşitli değişkenlere göre belirlenmesidir. Belirlenen bu amaç doğrultusunda aşağıdaki soruların yanıtı aranmaktadır:

a) SHMYO öğrencilerinin yazma kaygıları ve öz-yeterlik algılarına ilişkin puan ortalamaları ölçeklerin toplam puanları ve alt boyutlarında ne düzeydedir?

b) SHMYO öğrencilerinin yazma kaygıları cinsiyet, sınıf düzeyi, öğretim türü, mezun olunan lise türü, ailenin gelir düzeyi, ailenin ikamet yeri ve eğitim aldıkları branş değişkenlerine göre anlamlı düzeyde farklılık göstermekte midir? 


\section{ULUSLARARASI INTERNATIONAL \\ TÜRK EĞiTiM BILIMLERI DERGISi JOURNAL OF TURKISH EDUCATION SCIENCES \\ UTEB Y11 / Year: 7 | Sayı / Issue: 12 | Nisan / April 2019 \\ ISSN 2148-2314 $\mid$ uteb.gop.edu.tr}

c) SHMYO öğrencilerinin öz-yeterlik algıları cinsiyet, sınıf düzeyi, öğretim türü, mezun olunan lise türü, ailenin gelir düzeyi, ailenin ikamet yeri ve eğitim aldıkları branş değişkenlerine göre anlamlı düzeyde farklılık göstermekte midir?

d) SHMYO öğrencilerinin yazma kaygıları ile akademik öz-yeterlik algıları arasında anlamlı bir ilişki bulunmakta mıdır?

\section{YÖNTEM}

Araştırmanın bu bölümünde evren/örneklem, veri toplama araçları, verilerin toplanması ve analizine yönelik bilgilere yer verilmektedir.

\section{Evren ve Örneklem}

Bu çalışmaya dâhil edilen örneklem grubunun belirlenmesinde tarama modelleri arasında yer alan basit seçkisiz örnekleme yöntemi kullanılmıştır. Örneklem grubunu 2018-2019 eğitimöğretim yılı bahar döneminde Sivas Cumhuriyet Üniversitesi SHMYO'da eğitim görmekte olan 340 kız, 115 erkek olmak üzere toplamda 455 öğrenci oluşturmaktadır. 2018-219 yılı bahar döneminde, Sivas Cumhuriyet Üniversitesi SHMYO'da eğitim görmekte olan 3.679 öğrenci bulunduğu belirlenmiş ve bu sayının 0.05 anlamlılık düzeyine göre $\mathrm{d}= \pm 0.05$ örnekleme hatası (Sönmez ve Alacapınar, 2011: 338) temel alınarak araştırmaya katılan örneklem grubundaki öğrenci sayısı tespit edilmiştir. Tablo 1'de örnekleme ilişkin betimsel istatistikler sunulmaktadır.

Tablo 1. Örnekleme İlişkin Betimsel İstatistikler

\begin{tabular}{|c|c|c|c|}
\hline Değişkenler & & Frekans (f) & Yüzde (\%) \\
\hline \multirow{2}{*}{ Cinsiyet } & K1z & 340 & 74.73 \\
\hline & Erkek & 115 & 25.27 \\
\hline \multirow{2}{*}{ Sinif } & Birinci Sınıf & 265 & 58.24 \\
\hline & İkinci Sınıf & 190 & 41.76 \\
\hline \multirow{2}{*}{ Öğretim Türü } & Birinci Öğretim & 390 & 85.71 \\
\hline & İkinci Öğretim & 65 & 14.29 \\
\hline \multirow{4}{*}{ Gelir Seviyesi } & Çok iyi & 15 & 3.30 \\
\hline & İyi & 136 & 29.89 \\
\hline & Orta & 291 & 63.96 \\
\hline & Düşük & 13 & 2.86 \\
\hline \multirow{4}{*}{ Ailenin İkamet Yeri } & Köy & 82 & 18.02 \\
\hline & İlçe & 118 & 25.93 \\
\hline & Şehir & 195 & 42.86 \\
\hline & Büyükş̧ehir & 60 & 13.19 \\
\hline \multirow{4}{*}{ Okuduğu Lise Türü } & Genel & 35 & 7.69 \\
\hline & Meslek & 206 & 45.27 \\
\hline & İHL & 45 & 9.89 \\
\hline & Anadolu & 169 & 37.14 \\
\hline \multirow{9}{*}{ SHMYO Okuduğu Bölüm } & Ağız Diş Sağlı̆̆ & 53 & 11.65 \\
\hline & Ameliyathane & 40 & 8.79 \\
\hline & Çocuk Gelişimi & 71 & 15.60 \\
\hline & Diyaliz & 74 & 16.26 \\
\hline & Eczane & 35 & 7.69 \\
\hline & Odyometri & 37 & 8.13 \\
\hline & T1bbi Görüntüleme & 35 & 7.69 \\
\hline & Tibbi Laboratuvar & 53 & 11.65 \\
\hline & Yaşlı Bakım & 57 & 12.53 \\
\hline
\end{tabular}




\section{ULUSLARARASI INTERNATIONAL \\ TÜRK EĞiTiM BILIMLERI DERGISi JOURNAL OF TURKISH EDUCATION SCIENCES \\ UTEB Yıl / Year: 7 | Sayı / Issue: 12 | Nisan / April 2019 \\ ISSN 2148-2314 $\mid$ uteb.gop.edu.tr}

Tablo 1 incelendiğinde; öğrencilerin yaklaşık 3/4'ünün k1z öğrencilerden oluştuğu görülmekte olup, evrenin çoğunluğunun kız öğrencilerden oluştuğu görülmektedir. SHMYO öğrencilerinin ağırlıklı olarak kız öğrencilerden oluşması örneklem grubundaki bu oranın ortaya çıkmasında önemli bir etken olmaktadır. Katılımcıların yaklaşık \% 58'i birinci; yaklaşık \% 42'si ikinci sınıfta okuyan öğrencilerinden oluşmaktadır. Katılımcıların çoğunluğu birinci öğretime devam eden öğrencilerden \% 85.71 oluşmaktadır. İkinci öğretimde birinci öğretime göre daha az öğrencinin eğitim alması örneklem grubundaki bu sonucu doğurmaktadır. Katılımcıların gelir düzeyine ilişkin bilgilere bakıldığında, ağırlıklı olarak orta düzeyde olduğu \% 63.96 görülmektedir. Gelir düzeyini çok iyi $\% 3.30$ ya da düşük $\% 2.86$ olarak ifade eden öğrencilerin sayısının diğerlerine göre az olduğu belirlenmiştir. Öğrencilerin ailelerinin çoğunlukla şehirde ikâmet ettikleri \% 42.86, ailesi büyükşehirde yaşayan öğrencilerin sayısının en az olan grup olduğu \% 13.2 tespit edilmiştir. Katılımcıların büyük çoğunluğunun meslek lisesi çıkışlı \% 45.27 olduğu, ikinci sırada Anadolu lisesi çıkışıı öğrencilerin yer aldığ 1 \% 37.14; SHMYO’da dokuz farklı branşta eğitim aldıkları belirlenmiştir.

\section{Veri Toplama Araçları}

$\mathrm{Bu}$ araştırmada iki farklı ölçek kullanılmıştır. Öğrencilerin yazma kaygılarının belirlenmesi amaciyla Karakaya ve Ülper (2011) tarafindan geliştirilen tek boyut ve 35 maddeden oluşan "Yazma Kaygısı Ölçeği"; öz-yeterlik algılarının belirlenmesi amacıyla Sherer, Maddux, Mercandante, Dunn, Jacobs ve Rogers (1982) tarafından geliştirilen Türkçeye uyarlaması Yıldırım ve İlhan (2010) tarafından yapılan “Genel Öz-yeterlik Ölçeği

Yazma kaygısı ölçeği; Karakaya ve Ülper (2011) tarafından geliştirilmiş olup tek boyut ve 35 maddeden oluşmaktadır. Ölçeğin güvenirliği .97, bu çalışmada da .97 olarak tespit edilmiştir. Ölçek beşli likert tipinde hazırlanmış olup "Hiçbir Zaman=1", "Çok Az=2", "Bazen=3", "Çoğu Zaman=4" ve "Her Zaman=5" şeklinde derecelendirilmiştir. Ölçekten alınabilecek en yüksek puan 175 en düşük puan ise 35 'dir. Öğrencilerin aldıkları puanlar yükseldikçe yazma kaygılarının arttığı düştükçe azaldığı söylenebilir.

Genel öz-yeterlik ölçeği; Sherer, Maddux, Mercandante, Dunn, Jacobs ve Rogers (1982 tarafından geliştirilen Türkçeye uyarlaması Yıldırım ve İlhan (2010) tarafından yapılan "Genel Öz-yeterlik Ölçeği”, "Başlama" (9 madde), "Yılmama" (5 madde) ve "Sürdürme ÇabasıIsrar" (3 madde) olmak üzere üç alt boyuttan ve toplamda 17 maddeden oluşmaktadır. Ölçeğin güvenilirliği .80 , bu çalışmada ise .70 olarak bulunmuştur. Ölçekten alınabilecek en yüksek puan 85 en düşük puan ise 17 'dir. Öğrencilerin aldıkları puanlar yükseldikçe öz-yeterliklerinin arttığı, düştükçe azaldı ̆̆ı söylenebilir. Ölçekteki sorular, sizi ne kadar tanımlıyor olarak ifade edilmiş ve "hiç=1" ve "çok iyi=5" arasında puanlanan orijinal beşli likert tipindeki şekliyle kullanılmıştır.

\section{Verilerin Toplanması ve Analizi}

Araştırmanın verileri, 2018-2019 eğitim-öğretim y1lı bahar döneminde Sivas Cumhuriyet Üniversitesi SHMYO’da öğrenim görmekte olan öğrencilere ölçeklerin uygulanmasıyla elde edilmiştir. Ölçekler uygulanmadan önce gerekli izinler alınmış, uygulanırken de öğrenci gönüllülüğü dikkate alınmıştır. Ölçekler, toplamda 472 öğrenciye uygulanmış ancak ölçeklerin 17 tanesi gerekli özellikleri taşımadığı için çıkarılarak 455 ölçek değerlendirmeye alınmıştır. Verilerin analizi SPSS 25.0 istatistik programı kullanılarak yapılmıştır. Puanların normal dağılıp dağılmadığını belirlemek amacıyla Kolmogorov-Smirnov (K-S) Testi uygulanmıştır. 
Verilerin normallik analizleri yapılarak aritmetik ortalama ve standart sapma puanları belirlenmiştir. Yapılan bu testlerdeki bulgulara göre öğrencilerin öz-yeterliklerinin ve yazma kaygılarının demografik değişkenlere göre anlamlı olarak farklılaşıp farklılaşmadığını belirlemek amacıyla ANOVA ve bağımsız gruplar T testi kullanılmıştır. ANOVA testinin uygulandığ 1 değişkenler arasındaki farklılaşmanın hangi gruplar arasında olduğunu belirlemek amacıyla LSD testi yapılmıştır. Son olarak öz-yeterlik ile yazma kaygısı arasındaki ilişkiyi belirlemek için Pearson Korelasyon Katsayısı analizi yapılmıştır.

\section{BULGULAR}

Öz-yeterlik ölçeği ve yazma kaygısı ölçeğinin betimsel analizi yapılmış; en yüksek puanlar, ölçek ortalamaları ve standart sapma puanlarına ilişkin elde edilen veriler Tablo 2'de sunulmuştur.

Tablo 2. Ölçeklere İlişkin Betimsel İstatistikler

\begin{tabular}{lccccc}
\hline Ölçekler & N & $\begin{array}{c}\text { En düş. } \\
\text { puan }\end{array}$ & $\begin{array}{c}\text { En yük. } \\
\text { puan }\end{array}$ & $\overline{\mathbf{x}}$ & S \\
\hline Öz-yeterlik Top. & 455 & 17 & 85 & 45.70 & 7.72 \\
Başlama & 455 & 9 & 45 & 21.34 & 6.35 \\
Y1mama & 455 & 5 & 25 & 14.66 & 2.79 \\
Sürdürme Çabas1-Israr & 455 & 3 & 15 & 9.70 & 2.47 \\
Yazma kaygis1 & 455 & 35 & 175 & 78.93 & 29.52 \\
\hline
\end{tabular}

Tablo 2 incelendiğinde öz-yeterlik ölçeğinin tamamından alınan en düşük puanın 17, en yüksek puanın ise 85 olduğu, ögrencilerin öz-yeterliklerinin orta seviyede \% 53.76 olduğu görülmektedir. Öğrencilerin puanlarının; öz-yeterlik ölçeğinin başlama alt boyutunda orta düzeyde \% 47.42, y1lmama alt boyutunda orta düzeyde \% 58.64 ve sürdürme çabası alt boyutunda da orta düzeyde \% 64.67 olduğu; en yüksek puan ortalamasının sürdürme çabasıısrar faktörüne ait olduğu görülmektedir. Yazma kaygısı ölçeğinin en düşük puanın 35, en yüksek puanının ise 175 olacağı ve ölçekten alınan puana göre öğrencilerin yazma kaygılarının orta seviyede \% 45.10 olduğu tespit edilmiştir.

SHMYO öğrencilerinin cinsiyet değişkenine göre öz-yeterlik algıları ve yazma kaygılarının değişip değişmediğini belirlemek amacıyla uygulanan bağımsız gruplar t-testi sonucunda ulaşılan bulgular Tablo 3 'te sunulmuştur.

Tablo 3. SHMYO Öğrencilerinin Cinsiyet Değişkenine Göre Öz-Yeterlik Algıları Ve Yazma Kaygıları Bağımsız Gruplar t-Testi Bulguları

\begin{tabular}{|c|c|c|c|c|c|c|}
\hline & Cinsiyet & $\mathbf{N}$ & $\overline{\mathbf{x}}$ & $\mathbf{S}$ & $\mathbf{t}$ & $\mathbf{p}$ \\
\hline \multirow{2}{*}{ Öz-yeterlik Toplam } & $\mathrm{K} 1 \mathrm{z}$ & 340 & 45.85 & 7.47 & \multirow{2}{*}{0.73} & \multirow{2}{*}{0.46} \\
\hline & Erkek & 115 & 45.24 & 8.45 & & \\
\hline \multirow{2}{*}{ Başlama } & K1z & 340 & 21.24 & 6.37 & \multirow{2}{*}{0.55} & \multirow{2}{*}{0.58} \\
\hline & Erkek & 115 & 21.63 & 6.32 & & \\
\hline \multirow{2}{*}{ Y1lmama } & K1z & 340 & 14.74 & 2.66 & \multirow{2}{*}{0.99} & \multirow{2}{*}{0.32} \\
\hline & Erkek & 115 & 14.43 & 3.15 & & \\
\hline \multirow{2}{*}{ Sürdürme Çabası- Israr } & $\mathrm{K} 1 \mathrm{Z}$ & 340 & 9.87 & 2.37 & \multirow{2}{*}{2.60} & \multirow{2}{*}{0.00} \\
\hline & Erkek & 115 & 9.18 & 2.70 & & \\
\hline \multirow{2}{*}{ Yazma Kaygis1 } & $\mathrm{K}_{1 \mathrm{Z}}$ & 340 & 79.23 & 29.29 & \multirow{2}{*}{0.36} & \multirow{2}{*}{0.71} \\
\hline & Erkek & 115 & 78.05 & 30.32 & & \\
\hline
\end{tabular}


Tablo 3'te yer alan bulgular incelendiğinde öğrencilerin cinsiyet değişkenine göre öz-yeterlik algılarına ilişkin puanlarında ölçeğin sürdürme çabası-1srar alt boyutunda kız öğrenciler lehine anlamlı farklılık olduğu $\mathrm{p}<.05$; ölçeğin diğer alt boyutları, toplamı ve yazma kaygılarına göre ise anlamlı farklılığın bulunmadığı $\mathrm{p}>.05$ belirlenmiştir. Ölçeklerin toplam puanları açısından değerlendirildiğinde öğrencilerin öz-yeterliklerinin kız öğrencilerde daha yüksek olduğu; yazma kaygılarının ise kız öğrencilerde daha fazla görüldüğü belirlenmiştir.

SHMYO öğrencilerinin sınıf düzeyi değişkenine göre öz-yeterlik algılarının ve yazma kaygılarının değişip değişmediğini belirlemek amacıyla uygulanan bağımsız gruplar t-testi sonucunda ulaşılan bulgular Tablo 4'te sunulmuştur.

Tablo 4. SHMYO Öğrencilerinin Sınıf Değişkenine Göre Öz-Yeterlik Algıları Ve Yazma Kaygıları Bağımsız Gruplar t-Testi Bulguları

\begin{tabular}{|c|c|c|c|c|c|c|}
\hline & Sinıf & $\mathbf{N}$ & $\overline{\mathbf{x}}$ & $\mathbf{S}$ & $\mathbf{t}$ & p \\
\hline \multirow{2}{*}{ Öz-yeterlik Toplam } & 1 & 265 & 45.55 & 7.74 & \multirow{2}{*}{0.47} & \multirow{2}{*}{0.63} \\
\hline & 2 & 190 & 45.90 & 7.73 & & \\
\hline \multirow{2}{*}{ Başlama } & 1 & 265 & 21.27 & 6.43 & \multirow{2}{*}{0.28} & \multirow{2}{*}{0.77} \\
\hline & 2 & 190 & 21.44 & 6.26 & & \\
\hline \multirow{2}{*}{ Y1lmama } & 1 & 265 & 14.63 & 2.89 & \multirow{2}{*}{0.22} & \multirow{2}{*}{0.81} \\
\hline & 2 & 190 & 14.69 & 2.65 & & \\
\hline \multirow{2}{*}{ Sürdürme Çabas1-Israr } & 1 & 265 & 9.65 & 2.51 & \multirow{2}{*}{0.46} & \multirow{2}{*}{0.63} \\
\hline & 2 & 190 & 9.76 & 2.42 & & \\
\hline \multirow{2}{*}{ Yazma Kaygıs1 } & 1 & 265 & 80.38 & 30.51 & \multirow{2}{*}{1.23} & \multirow{2}{*}{0.21} \\
\hline & 2 & 190 & 76.91 & 28.06 & & \\
\hline
\end{tabular}

Tablo 4'te sunulan analiz sonuçlarına göre; sınıf değişkenine göre öz-yeterlik algılarının ikinci sınıf öğrencilerinde daha yüksek olduğu fakat anlamlı farklılık göstermediği $\mathrm{p}>.05$; yazma kaygılarının da birinci sınıf öğrencilerinde daha yüksek olduğu fakat anlamlı farklılık göstermediği $\mathrm{p}>.05$ belirlenmiştir. Her iki veri de birbiriyle uyumluluk göstermektedir. Birinci sınıf öğrencilerinin öz-yeterlik seviyeleri daha düşük ama yazma kaygıları ikinci sınıflara göre daha yüksektir. Öz-yeterliğin öğrencilerin yazma kaygısı üzerinde olumlu etkisinin olduğu savunulabilir.

SHMYO öğrencilerinin öğretim türü değişkenine göre öz-yeterlik algılarının ve yazma kaygılarının farklılaşıp farklılaşmadığını belirlemek amacıyla uygulanan bağımsız gruplar ttesti sonucunda ulaşılan bulgular Tablo 5'te sunulmuştur.

Tablo 5. SHMYO Öğrencilerinin Öğretim Türü Değişkenine Göre Öz-Yeterlik Algıları Ve Yazma Kaygıları Bağımsız Gruplar t-Testi Bulguları

\begin{tabular}{|c|c|c|c|c|c|c|}
\hline & Öğretim Türü & $\mathbf{N}$ & $\overline{\mathbf{x}}$ & $\mathbf{S}$ & $\mathbf{t}$ & $\mathbf{p}$ \\
\hline \multirow{2}{*}{ Öz-yeterlik Toplam } & Birinci Öğretim & 390 & 45.71 & 7.67 & \multirow{2}{*}{0.07} & \multirow{2}{*}{0.93} \\
\hline & İkinci Öğretim & 65 & 45.63 & 8.10 & & \\
\hline \multirow{2}{*}{ Başlama } & Birinci Öğretim & 390 & 21.39 & 6.33 & \multirow{2}{*}{0.44} & \multirow{2}{*}{0.65} \\
\hline & İkinci Öğretim & 65 & 21.02 & 6.55 & & \\
\hline \multirow{2}{*}{ Y1lmama } & Birinci Öğretim & 390 & 14.65 & 2.74 & \multirow{2}{*}{0.15} & \multirow{2}{*}{0.88} \\
\hline & İkinci Öğrenim & 65 & 14.71 & 3.09 & & \\
\hline \multirow{2}{*}{ Sürdürme Çabas1- Israr } & Birinci Öğretim & 390 & 9.66 & 2.45 & \multirow{2}{*}{0.73} & \multirow{2}{*}{0.46} \\
\hline & İkinci Öğretim & 65 & 9.91 & 2.62 & & \\
\hline \multirow{2}{*}{ Yazma Kaygis1 } & Birinci Öğretim & 390 & 79.77 & 29.63 & \multirow{2}{*}{1.48} & \multirow{2}{*}{0.13} \\
\hline & İkinci Öğretim & 65 & 73.89 & 28.64 & & \\
\hline
\end{tabular}


Tablo 5'te yer alan sonuçlara bakıldığında; öğretim türü değişkenine göre öğrencilerin özyeterlik algılarının toplam puanda ve alt boyutlarda anlamlı farklılık göstermediği p>.05, puanların birbirine çok yakın olduğu görülmektedir. Öğrencilerin yazma kaygılarının ise birinci öğretim öğrencilerde daha yüksek olduğu fakat anlamlı farklılık göstermediği p>.05 belirlenmiştir.

SHMYO öğrencilerinin öz-yeterlik algıları ve yazma kaygılarının gelir düzeyi değişkeni açısından anlamlı bir şekilde farklılaşıp farklılaşmadığını belirlemeye yönelik olarak yapılan ANOVA testi sonuçları Tablo 6'da sunulmuştur.

Tablo 6. SHMYO Öğrencilerinin Gelir Durumu Değişkenine Göre Öz-Yeterlik Algıları Ve Yazma Kaygiları ANOVA Testi Bulguları

\begin{tabular}{|c|c|c|c|c|c|c|c|}
\hline & $\begin{array}{l}\text { Gelir } \\
\text { Düz. }\end{array}$ & $\mathbf{N}$ & $\overline{\mathbf{x}}$ & $\mathbf{S}$ & $\mathbf{F}$ & $\mathbf{p}$ & $\begin{array}{c}\text { Anlamlı Fark } \\
\text { LSD }\end{array}$ \\
\hline & Çok iyi & 15 & 47.00 & 9.91 & \multirow{4}{*}{.533} & \multirow{4}{*}{.66} & \multirow{4}{*}{ Yok } \\
\hline Öz-yeterlik & İyi & 136 & 45.06 & 8.11 & & & \\
\hline Toplam & Orta & 291 & 45.89 & 7.32 & & & \\
\hline & Düşük & 13 & 45.43 & 8.31 & & & \\
\hline \multirow{4}{*}{ Başlama } & Çok iyi & 15 & 20.93 & 8.04 & \multirow{4}{*}{1.395} & \multirow{4}{*}{.24} & \multirow{4}{*}{ Yok } \\
\hline & İyi & 136 & 20.69 & 6.27 & & & \\
\hline & Orta & 291 & 21.51 & 6.23 & & & \\
\hline & Düşük & 13 & 24.00 & 7.91 & & & \\
\hline \multirow{4}{*}{ Y1lmama } & Çok iyi & 15 & 16.00 & 3.80 & \multirow{4}{*}{2.507} & \multirow{4}{*}{$0.04^{*}$} & \multirow{4}{*}{$\begin{array}{l}\text { Çok iyi-Düşük* } \\
\text { Orta-Düşük }\end{array}$} \\
\hline & İyi & 136 & 14.59 & 2.81 & & & \\
\hline & Orta & 291 & 14.71 & 2.68 & & & \\
\hline & Düşük & 13 & 13.21 & 2.75 & & & \\
\hline \multirow{4}{*}{$\begin{array}{l}\text { Sürdürme } \\
\text { çabasi-Israr }\end{array}$} & Çok iyi & 15 & 10.07 & 2.58 & \multirow{4}{*}{1.842} & \multirow{4}{*}{$.04^{*}$} & \multirow{4}{*}{$\begin{array}{l}\text { Çok iyi-Düşük* } \\
\text { İyi-Düşük* } \\
\text { Orta-Düşük }\end{array}$} \\
\hline & İyi & 136 & 9.78 & 2.64 & & & \\
\hline & Orta & 291 & 9.68 & 2.34 & & & \\
\hline & Düşük & 13 & 8.21 & 3.24 & & & \\
\hline \multirow{4}{*}{ Yazma kayg1s1 } & Çok iyi & 15 & 76.53 & 33.71 & \multirow{4}{*}{2.83} & \multirow{4}{*}{$0.03^{*}$} & \multirow{4}{*}{ İyi-Orta* } \\
\hline & İyi & 136 & 72.95 & 26.81 & & & \\
\hline & Orta & 291 & 81.68 & 29.99 & & & \\
\hline & Düşük & 13 & 82.61 & 34.90 & & & \\
\hline
\end{tabular}

${ }^{*} \mathrm{p}<.05$

Tablo 6'da bulunan bulgular incelendiğinde SHMYO öğrencilerinin öz-yeterliklerinin ölçeğin yılmama ve sürdürme çabası alt boyutlarında anlamlı farklılık gösterdiği $\mathrm{p}<.05$ başlama ve toplam puanda ise anlamlı farklılık göstermediği $\mathrm{p}>.05$ belirlenmiştir. Hangi gruplar arasında anlamlı farklılık olduğunun belirlenmesi için yapılan LSD testi sonuçlarına göre ölçeğin yılmama alt boyutunda "Çok iyi-Düşük" ve "Orta-Düşük"; sürdürme çabası alt boyutunda "Çok iyi-Düşük”, "Iyi-Düşük” ve "Orta-Düşük”" grupları arasında gelir seviyesini düşük olarak ifade eden grup aleyhine olduğu belirlenmiştir. Toplam puan açısından bakıldığında özyeterlik puanlarının gelir düzeyini çok iyi olarak ifade eden öğrencilerde en yüksek, düşük olarak ifade eden öğrencilere ise en düşük olduğu görülmektedir. Öğrencilerin yazma kaygılarının gelir düzeyi değişkenine göre anlamlı farklılık gösterdiği $\mathrm{p}<.05$ ve bu farklılığın "İyi-Orta" grupları arasında iyi lehine olduğu tespit edilmiştir. Yazma kaygısının gelir düzeyini iyi olarak değerlendiren öğrencilerde en düşük, gelir düzeyini düşük olarak değerlendirenlerde ise en yüksek çıktığı saptanmıştır. 
SHMYO öğrencilerinin öz-yeterlik algılarının ve yazma kaygılarının ailenin ikamet yeri değişkeni açısından anlamlı bir şekilde farklılaşıp farklılaşmadığını belirlemeye yönelik olarak yapılan ANOVA testi sonuçları Tablo 7'de sunulmuştur.

Tablo 7. SHMYO Öğrencilerinin İkamet Yeri Değişkenine Göre Öz-Yeterlik Algıları Ve Yazma Kaygıları ANOVA Testi Bulguları

\begin{tabular}{|c|c|c|c|c|c|c|c|}
\hline & İka. Yeri & $\mathbf{N}$ & $\overline{\mathbf{x}}$ & $\mathbf{S}$ & $\mathbf{F}$ & $\mathbf{p}$ & $\begin{array}{c}\text { Anlamlı Fark } \\
\text { LSD }\end{array}$ \\
\hline & Köy & 82 & 45.80 & 6.60 & \multirow{4}{*}{.687} & \multirow{4}{*}{.60} & \multirow{4}{*}{ Yok } \\
\hline Öz-yeterlik & İlçe & 118 & 45.15 & 7.45 & & & \\
\hline \multirow[t]{2}{*}{ Toplam } & Şehir & 195 & 45.78 & 8.22 & & & \\
\hline & B. Şehir & 60 & 46.56 & 7.74 & & & \\
\hline \multirow{4}{*}{ Başlama } & Köy & 82 & 21.79 & 5.95 & \multirow{4}{*}{.833} & \multirow{4}{*}{.51} & \multirow{4}{*}{ Yok } \\
\hline & İlçe & 118 & 20.86 & 6.16 & & & \\
\hline & Şehir & 195 & 21.30 & 6.78 & & & \\
\hline & B. Şehir & 60 & 22.02 & 5.96 & & & \\
\hline \multirow{4}{*}{ Yilmama } & Köy & 82 & 14.46 & 2.34 & \multirow{4}{*}{.170} & \multirow{4}{*}{.95} & \multirow{4}{*}{ Yok } \\
\hline & İlçe & 118 & 14.65 & 2.86 & & & \\
\hline & Şehir & 195 & 14.74 & 2.85 & & & \\
\hline & B. Şehir & 60 & 14.76 & 2.93 & & & \\
\hline \multirow{4}{*}{$\begin{array}{l}\text { Sürdürme } \\
\text { çabas1-Israr }\end{array}$} & Köy & 82 & 9.55 & 2.10 & \multirow{4}{*}{.137} & \multirow{4}{*}{.97} & \multirow{4}{*}{ Yok } \\
\hline & İlçe & 118 & 9.63 & 2.57 & & & \\
\hline & Şehir & 195 & 9.75 & 2.55 & & & \\
\hline & B. Şehir & 60 & 9.78 & 2.66 & & & \\
\hline \multirow{4}{*}{ Yazma kayg1s1 } & Köy & 82 & 81.30 & 30.79 & \multirow{4}{*}{2.091} & \multirow{4}{*}{.04} & \multirow{4}{*}{ Şehir-B.şehir ${ }^{*}$} \\
\hline & İlçe & 118 & 81.27 & 30.28 & & & \\
\hline & Şehir & 195 & 74.75 & 28.09 & & & \\
\hline & B. Şehir & 60 & 84.68 & 29.72 & & & \\
\hline
\end{tabular}

${ }^{*} \mathrm{p}<05$

Tablo 7 incelendiğinde SHMYO öğrencilerinin ikamet yeri değişkenine göre öz-yeterlik puanlarının alt boyutlar ve toplam puanda anlamlı olarak farklılaşmadığı $\mathrm{p}>.05$; yazma kaygılarının ise farklılaştığı $\mathrm{p}<.05$ tespit edilmiştir. Yazma kaygısı puanlarının hangi gruplar arasında farklılaştığının belirlenmesi amacıyla yapılan LSD testinin sonuçlarına göre "ŞehirBüyükşehir" grupları arasında büyükşehir lehine olmak üzere anlamlı farklılık olduğu görülmüştür.

SHMYO öğrencilerinin öz-yeterlik algıları ve yazma kaygılarının mezun olunan lise türü değişkeni açısından anlamlı bir şekilde farklılaşıp farklılaşmadığını belirlemeye yönelik olarak yapılan ANOVA testi sonuçları Tablo 8'de sunulmuştur.

Tablo 8. SHMYO Öğrencilerinin Mezun Oldukları Lise Türü Değişkenine Göre Öz-Yeterlik Algıları Ve Yazma Kaygıları ANOVA Testi Bulguları

\begin{tabular}{|c|c|c|c|c|c|c|c|}
\hline & $\begin{array}{l}\text { Lise } \\
\text { Türü }\end{array}$ & $\mathbf{N}$ & $\overline{\mathbf{x}}$ & $\mathbf{S}$ & $\mathbf{F}$ & $\mathbf{p}$ & $\begin{array}{c}\text { Anlamlı Fark } \\
\text { LSD }\end{array}$ \\
\hline & Genel & 35 & 45.93 & 5.63 & \multirow{4}{*}{.148} & \multirow{4}{*}{.93} & \multirow{4}{*}{ Yok } \\
\hline Öz-yeterlik & Meslek & 206 & 45.87 & 8.08 & & & \\
\hline \multirow[t]{2}{*}{ Toplam } & İHL & 45 & 45.63 & 7.51 & & & \\
\hline & Anadolu & 169 & 45.37 & 7.60 & & & \\
\hline
\end{tabular}


ULUSLARARASI | INTERNATIONAL

TÜRK EĞiTiM BíLIMLERI DERGISi JOURNAL OF TURKISH EDUCATION SCIENCES

UTEB Y11 / Year: 7 | Sayı / Issue: 12 | Nisan / April 2019

ISSN 2148-2314 $\mid$ uteb.gop.edu.tr

\begin{tabular}{|c|c|c|c|c|c|c|c|}
\hline \multirow{4}{*}{ Başlama } & Genel & 35 & 20.47 & 5.61 & \multirow{4}{*}{.364} & \multirow{4}{*}{.78} & \multirow{4}{*}{ Yok } \\
\hline & Meslek & 206 & 21.59 & 6.84 & & & \\
\hline & İHL & 45 & 21.00 & 5.74 & & & \\
\hline & Anadolu & 169 & 21.21 & 6.09 & & & \\
\hline \multirow{4}{*}{ Y1lmama } & Genel & 35 & 15.60 & 1.71 & \multirow{4}{*}{1.236} & \multirow{4}{*}{.30} & \multirow{4}{*}{ Yok } \\
\hline & Meslek & 206 & 14.62 & 2.79 & & & \\
\hline & İHL & 45 & 14.67 & 3.00 & & & \\
\hline & Anadolu & 169 & 14.56 & 2.84 & & & \\
\hline \multirow{4}{*}{$\begin{array}{l}\text { Sürdürme } \\
\text { çabas1-Israr }\end{array}$} & Genel & 35 & 9.87 & 2.30 & \multirow{4}{*}{.325} & \multirow{4}{*}{.81} & \multirow{4}{*}{ Yok } \\
\hline & Meslek & 206 & 9.66 & 2.54 & & & \\
\hline & İHL & 45 & 9.96 & 2.34 & & & \\
\hline & Anadolu & 169 & 9.60 & 2.49 & & & \\
\hline \multirow{4}{*}{ Yazma kaygis1 } & Genel & 35 & 76.70 & 29.11 & \multirow{4}{*}{.066} & \multirow{4}{*}{.98} & \multirow{4}{*}{ Yok } \\
\hline & Meslek & 206 & 79.11 & 29.65 & & & \\
\hline & İHL & 45 & 79.24 & 27.16 & & & \\
\hline & Anadolu & 169 & 79.22 & 30.18 & & & \\
\hline
\end{tabular}

Tablo 8 incelendiğinde SHMYO öğrencilerinin öz-yeterlik algıları ve yazma kaygılarına ilişkin puanlarının mezun oldukları lise türüne göre anlamlı olarak farklılaşmadığ 1 p $>.05$ tespit edilmiştir.

SHMYO öğrencilerinin öz-yeterlik algılarının branş değişkeni açısından anlamlı bir şekilde farklılaşıp farklılaşmadığını belirlemeye yönelik olarak yapılan ANOVA testi sonuçları Tablo 9'da sunulmuştur.

Tablo 9. SHMYO Öğrencilerinin Branş Değişkenine Göre Öz-Yeterlik Algıları ANOVA Testi Bulguları

\begin{tabular}{|c|c|c|c|c|c|c|c|}
\hline & Branş & $\mathbf{N}$ & $\overline{\mathbf{x}}$ & $\mathbf{S}$ & $\mathbf{F}$ & p & Anlamlı Fark LSD \\
\hline \multirow{9}{*}{$\begin{array}{l}\text { Öz- } \\
\text { yeterlik } \\
\text { Toplam }\end{array}$} & Ağız Diș Sağlığı & 53 & 46.49 & 6.57 & \multirow{9}{*}{1.723} & \multirow{9}{*}{$.02^{*}$} & \multirow{9}{*}{$\begin{array}{c}\text { Ağız diş sağ.-Yaşlı bak. }{ }^{*} \\
\text { Diyaliz-Yaşlı bak. } \\
\text { Eczane-Yaşlı bak. }{ }^{*} \\
\text { Odyometri-Yaşlı bak. }\end{array}$} \\
\hline & Ameliyathane & 40 & 45.73 & 5.46 & & & \\
\hline & Çocuk Gelişimi & 71 & 45.07 & 7.61 & & & \\
\hline & Diyaliz & 74 & 46.51 & 6.94 & & & \\
\hline & Eczane & 35 & 47.26 & 8.46 & & & \\
\hline & Odyometri & 37 & 47.32 & 7.08 & & & \\
\hline & Tıbbi Görüntüleme & 35 & 44.71 & 7.47 & & & \\
\hline & Tibbi Laboratuvar & 53 & 45.68 & 8.38 & & & \\
\hline & Yaş11 Bakım & 57 & 42.82 & 9.77 & & & \\
\hline \multirow{9}{*}{ Başlama } & Ağız Diş Sağl1ğı & 53 & 21.30 & 5.54 & \multirow{9}{*}{1.089} & \multirow{9}{*}{$.04^{*}$} & \multirow{9}{*}{$\begin{array}{l}\text { Diyaliz-Yaşlı bak. }{ }^{*} \\
\text { Odyometri-Yaşlı bak. }\end{array}$} \\
\hline & Ameliyathane & 40 & 21.13 & 6.33 & & & \\
\hline & Çocuk Gelişimi & 71 & 20.85 & 6.47 & & & \\
\hline & Diyaliz & 74 & 21.98 & 6.62 & & & \\
\hline & Eczane & 35 & 22.40 & 6.62 & & & \\
\hline & Odyometri & 37 & 22.95 & 5.87 & & & \\
\hline & Tıbbi Görüntüleme & 35 & 21.57 & 5.29 & & & \\
\hline & Tibbi Laboratuvar & 53 & 20.64 & 6.49 & & & \\
\hline & Yaşlı Bakım & 57 & 19.79 & 7.13 & & & \\
\hline \multirow{5}{*}{ Y1lmama } & Ağız Diş Sağlığı & 53 & 15.25 & 2.66 & \multirow{5}{*}{1.547} & \multirow{5}{*}{$.04^{*}$} & \multirow{5}{*}{$\begin{array}{l}\text { Ağız diş sağ.-Çocuk gel."* } \\
\text { Ağız diş sağ.-Yaşlı bak." } \\
\text { Ameliyathane.-Yaşlı bak." } \\
\text { Diyaliz-Yaşlı bak. }\end{array}$} \\
\hline & Ameliyathane & 40 & 15.15 & 2.37 & & & \\
\hline & Çocuk Gelişimi & 71 & 14.20 & 2.61 & & & \\
\hline & Diyaliz & 74 & 14.93 & 2.51 & & & \\
\hline & Eczane & 35 & 14.91 & 2.82 & & & \\
\hline
\end{tabular}




\begin{tabular}{|c|c|c|c|c|c|c|}
\hline & Odyometri & 37 & 14.97 & 2.63 & & \\
\hline & Tibbi Görüntüleme & 35 & 14.14 & 2.81 & & \\
\hline & Tibbi Laboratuvar & 53 & 14.70 & 2.55 & & \\
\hline & Yaşlı Bakım & 57 & 13.93 & 3.73 & & \\
\hline \multirow{9}{*}{$\begin{array}{l}\text { Sürdürme } \\
\text { çabas1- } \\
\text { 1srar }\end{array}$} & Ağız Diş Sağlığı & 53 & 9.94 & 2.13 & \multirow{9}{*}{$1.603 .03^{*}$} & \multirow{9}{*}{$\begin{array}{l}\text { Çocuk gel.-Tıbbi gör." } \\
\text { Çocuk gel.-Yaşlı bak." } \\
\text { T1bbi lab.-T1bbi gör." } \\
\text { T1bbi lab.-Yaşlı bak." }\end{array}$} \\
\hline & Ameliyathane & 40 & 9.45 & 2.05 & & \\
\hline & Çocuk Gelişimi & 71 & 10.03 & 2.41 & & \\
\hline & Diyaliz & 74 & 9.61 & 2.25 & & \\
\hline & Eczane & 35 & 9.94 & 2.82 & & \\
\hline & Odyometri & 37 & 9.41 & 2.77 & & \\
\hline & Tıbbi Görüntüleme & 35 & 9.00 & 2.34 & & \\
\hline & Tibbi Laboratuvar & 53 & 10.34 & 2.44 & & \\
\hline & Yaşlı Bakım & 57 & 9.11 & 3.01 & & \\
\hline
\end{tabular}

Tablo 9'da bulunan bulgular incelendiğinde SHMYO öğrencilerinin öz-yeterliklerinin branş değişkenine göre toplam puan ve tüm alt boyutlarda anlamlı olarak farklılık gösterdiği $\mathrm{p}<.05$ belirlenmiştir. $\mathrm{Bu}$ farklılığın hangi gruplar arasında olduğunun belirlenmesi amacıyla yapılan LSD testi sonucuna göre; toplam puanda "A $\breve{g l z}$ ve Diş Sağlı ğı-Yaşlı Bakımı", "Diyaliz-Yaşlı Bakımı", "Eczane-Yaşlı Bakımı", "Odyometri-Yaşlı Bakımı" arasında yaşlı bakımı aleyhine; başlama alt boyutunda "Diyaliz-Yaşlı Bakımı", Odyometri-Yaşlı Bakımı" arasında yaşlı bakımı

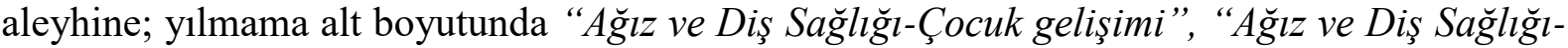
Yaşlı Bakımı" arasında ağız ve diş sağlığı lehine, "Ameliyathane-Yaşlı Bakımı", "Diyaliz-Yaşlı Bakımı" arasında yaşlı bakımı aleyhine; sürdürme çabası alt boyutunda ise "Çocuk GelişimiTıbbi Görüntüleme”, "Çocuk Gelişimi-Yaşlı Bakımı" arasında çocuk gelişimi lehine, "Tıbbi Laboratuvar-Tıbbi Görüntüleme", "Tıbbi Laboratuvar-Yaşlı Bakımı" arasında tıbbi laboratuvar lehine anlamlı farklılı̆̆ın olduğu tespit edilmiştir. Toplam puana bakıldığında özyeterlik algısı en yüksek olan grubun odyometri en düşük olan grubun ise yaşlı bakımı olduğu görülmektedir.

SHMYO öğrencilerinin yazma kaygılarının branş değişkeni açısından anlamlı bir şekilde farklılaşıp farklılaşmadığını belirlemeye yönelik olarak yapılan ANOVA testi sonuçları Tablo 10 'da sunulmuştur.

Tablo 10. SHMYO Öğrencilerinin Branş Değişkenine Göre Yazma Kaygıları ANOVA Testi Bulguları

\begin{tabular}{|c|c|c|c|c|c|c|c|}
\hline & Branş & $\mathbf{N}$ & $\overline{\mathbf{x}}$ & $\mathbf{S}$ & $\mathbf{F}$ & p & Anlamlı Fark LSD \\
\hline \multirow{9}{*}{$\begin{array}{l}\text { Yazma } \\
\text { kaygis1 }\end{array}$} & Ağız Diş Sağlı̆̆1 & 53 & 89.51 & 35.39 & \multirow{9}{*}{2.750} & \multirow{9}{*}{$.01^{*}$} & Ağız diș sağ.-Çocuk gel." \\
\hline & Ameliyathane & 40 & 85.35 & 26.26 & & & Ağız diș sağ.-Eczane* \\
\hline & Çocuk Gelişimi & 71 & 73.39 & 27.20 & & & Ağı diș sağ.-Tıbbi gör." \\
\hline & Diyaliz & 74 & 84.14 & 28.20 & & & Ağ $1 z$ diș sağ.-Tıbbi lab." \\
\hline & Eczane & 35 & 73.83 & 28.98 & & & Ağız diș sağ.-Yaşlı bak." \\
\hline & Odyometri & 37 & 83.57 & 30.38 & & & Çocuk gel.-Ameliyathane ${ }^{*}$ \\
\hline & Tıbbi Görüntüleme & 35 & 75.34 & 26.06 & & & Çocuk gel.-Diyaliz* \\
\hline & Tibbi Laboratuvar & 53 & 73.17 & 28.70 & & & Diyaliz-Tıbbi lab.* \\
\hline & Yaşlı Bakım & 57 & 72.16 & 29.06 & & & Diyaliz-Yaşlı bak.* \\
\hline
\end{tabular}

Tablo 10'da bulunan bulgular incelendiğinde SHMYO öğrencilerinin yazma kaygılarının branş değişkenine göre anlamlı olarak farklılık gösterdiği $\mathrm{p}<.05$ belirlenmiştir. Bu farklılığın hangi gruplar arasında olduğunun belirlenmesi amacıyla yapılan LSD testi sonucuna göre; " $A \breve{g} l z v e$ 


\section{ULUSLARARASI INTERNATIONAL \\ TÜRK EĞiTiM BILIMLERI DERGISi JOURNAL OF TURKISH EDUCATION SCIENCES \\ UTEB Y11 / Year: 7 | Sayı / Issue: 12 | Nisan / April 2019 \\ ISSN 2148-2314 $\mid$ uteb.gop.edu.tr}

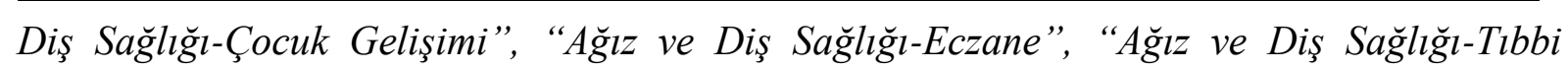

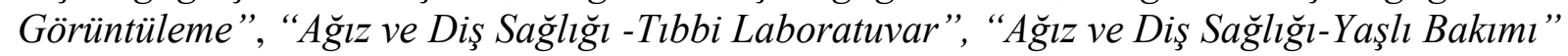
arasında ağız ve diş sağlığı lehine, "Çocuk Gelişimi-Ameliyathane", "Çocuk Gelişimi-Diyaliz" arasında çocuk gelişimi aleyhine, "Diyaliz-Tıbbi Laboratuvar", "Diyaliz-Yaşlı Bakımı", arasında diyaliz lehine anlamlı farklılığın oluştuğu saptanmıştır.

SHMYO öğrencilerinin öz-yeterlik algıları ile yazma kaygılarının alt boyutlar ve toplam puana göre aralarındaki korelasyon düzeyinin belirlenmesi amacıyla yapılan Pearson Korelasyon testi sonuçlarına Tablo 11'de yer verilmiştir.

Tablo 11. SHMYO Öğrencilerinin Öz-Yeterlik Algıları İle Yazma Kaygıları Korelasyon Testi Sonuçları

\begin{tabular}{|c|c|c|c|c|c|}
\hline & $\begin{array}{l}\text { Öz-yeterlik } \\
\text { top. }\end{array}$ & Başlama & Yilmama & Sürdürme çab. & $\begin{array}{l}\text { Yazma } \\
\text { kayggs } 1\end{array}$ \\
\hline Öz-yeterlik top. & 1.00 & $.82^{*}$ & $.63^{*}$ & ,68* & $-.34^{*}$ \\
\hline Başlama & & 1,00 & $.47 *$ & $.48^{*}$ & $-.41^{*}$ \\
\hline Yilmama & & & 1,00 & $.42^{*}$ & $-.21^{*}$ \\
\hline Sürdürme çab. & & & & 1,00 & $-.32^{*}$ \\
\hline Yazma kaygısı & & & & & 1,00 \\
\hline
\end{tabular}

Tablo 11'de yer alan bulgular incelendiğinde öğrencilerin yazma kaygısı ölçeğinden aldıkları puan ile öz-yeterlik ölçeğinden aldıkları puanlar arasında negatif yönde bir ilişkinin olduğu görülmektedir. Yazma kaygısı ile öz-yeterlik toplam puanı arasında negatif yönde orta düzeyde ( $\mathrm{r}=-.34)$, yazma kaygısı ile öz-yeterlik ölçeğinin başlama alt boyutu arasında negatif yönde orta düzeyde ( $\mathrm{r}=-.41)$, yazma kaygısı ile ölçeğin yılmama alt boyutu arasında negatif yönde düşük düzeyde $(\mathrm{r}=-.21)$, yazma kaygısı ile ölçeğin sürdürme çabası alt boyutu arasında negatif yönde orta düzeyde $(r=-.32)$ bir ilişkinin olduğu tespit edilmiştir. Öğrencilerin öz-yeterlik düzeyleri ile yazma kaygıları arasında negatif yönlü bir ilişki tespit edilmiş olması, öz-yeterlikleri arttıkça yazma kaygılarının azalacağı şeklinde yorumlanabilir.

\section{TARTIŞMA SONUÇ VE ÖNERILER}

Öz-yeterlik ölçeğinden alınan en düşük puanın 17, en yüksek puanın ise 85 olduğu ve ölçekten alınan puan ortalamalarına göre öğrencilerin öz-yeterliklerinin alt boyutlar ve toplam puanda orta seviyede olduğu görülmektedir. Yazma kaygısı ölçeğinin en düşük puanının 35, en yüksek puanının ise 175 olacağı ve ölçekten alınan puan ortalamasına göre öğrencilerin yazma kaygılarının orta seviyede olduğu tespit edilmiştir. Altıntaş ve Kaya (2012); Coşkun (2007) tarafından yapılan araştırma bulgularına göre bu çalışmayla uyumlu olarak öğrencilerin özyeterlik algılarının orta düzeyde olduğu saptanmıştır. Arslan (2018b) tarafından yapılan çalışmada öğrencilerin orta düzeyde yazma kaygısı, yüksek düzeyde öz-yeterlik algısına sahip oldukları belirlenmiştir. Ateş ve Akaydın'ın (2015) araştırma sonuçlarında da öğrencilerin orta düzeyde yazma kaygısına sahip oldukları tespit edilmiştir.

Öğrencilerin cinsiyet değişkenine göre öz-yeterlik ölçeğinin sürdürme çabası-1srar alt boyutunda kız öğrenciler lehine anlamlı farklılık olduğu ölçeğin diğer alt boyutları, toplamı ve yazma kaygısı ölçeğinden alınan puanlarda ise anlamlı farklılığın bulunmadığı belirlenmiştir. Ölçeklerin toplam puanları açısından değerlendirildiğinde öğrencilerin öz-yeterliklerinin kız öğrencilerde daha yüksek olduğu; yazma kaygılarının ise kız öğrencilerde daha fazla görüldüğü belirlenmiştir. Koç ve Arslan (2017) tarafından yapılan araştırma bulgularında öğrencilerin özyeterlik algılarının cinsiyet değişkeni açısından anlamlı farklılık oluşturduğu tespit edilmiştir. 


\section{ULUSLARARASI INTERNATIONAL TÜRK EĞiTIM BiLIMLERI DERGISi JOURNAL OF TURKISH EDUCATION SCIENCES \\ UTEB Yı1 /Year: 7 | Sayı / Issue: 12 | Nisan / April 2019 \\ ISSN 2148-2314 $\mid$ uteb.gop.edu.tr}

Arslan'ın (2017b, 2018a) ortaokul düzeyinde yaptığı araştırma bulgularında da öz-yeterlik üzerinde cinsiyet faktörünün belirleyici olduğu görülmüştür. Aksu'nun (2008) öğretmen adaylarına yönelik yaptığı çalışmada cinsiyet değişkenine göre anlamlı farklılık bulunmamıştır. Akbaş ve Çelikkaleli (2006) tarafından yapılan araştırma sonuçlarına göre öğrencilerin özyeterlik algılarının cinsiyet değişkenine göre farklılık göstermediği tespit edilmiştir. Arslan (2018b) tarafından yapılan çalışmada öğrencilerin yazma kaygılarının cinsiyet değişkenine göre kız öğrenciler lehine olmak üzere anlamlı farklılık gösterdiği bulgusuna ulaşılmıştır. Ateş ve Akaydın'ın (2015) araştırmasında cinsiyet değişkeni açısından kız öğrenciler lehine olmak üzere anlamlı farklılık görülmüştür. Yapılan araştırmalarda kız öğrencilerin yazma kaygılarının genel olarak erkek öğrencilerden daha düşük düzeyde olduğu görülmektedir. $\mathrm{Bu}$ sonuç kız öğrencilerin akademik anlamda daha başarılı olduklarını ortaya koyan çalışmalarla uyumluluk göstermektedir. Memiş ve Arıcan (2013) tarafından yapılan çalışmada kız öğrencilerin öğrenmeye yönelik üstbiliş stratejilerini erkek öğrencilere göre daha yüksek düzeyde kullanabildikleri belirlenmiştir. $\mathrm{Bu}$ doğrultuda k1z öğrencilerin öğrenme ortamlarında yaşadıkları olumsuz duygu ve durumlarla daha kolay baş edebilecekleri savunulabilmektedir. Kız öğrencilerin yazma kaygılarının düşük olmasında yazılı anlatım ödevlerini daha dikkatli yapmaları dolayısıyla öğretmenlerinden aldıkları olumlu dönütlerin etkili olduğu belirtilmektedir (Daly, 1985: 47).

Sınıf düzeyi değişkenine göre öz-yeterlik algılarının ikinci sınıf öğrencilerinde daha yüksek olduğu fakat anlamlı farklılık göstermediği belirlenmiştir. Yazma kaygısının ise birinci sınıf öğrencilerinde daha yüksek olduğu fakat anlamlı farklılık göstermediği belirlenmiştir. Her iki veri de birbiriyle uyumluluk göstermektedir. Beklenilen sonuç öz-yeterlikle yazma kaygısının ters orantılı olmasıdır. Bu çalışmada da birinci sınıf öğrencilerinin öz-yeterlik seviyeleri daha düşük ama yazma kaygıları ikinci sınıflara göre daha yüksektir. Öz-yeterliğin öğrencilerin yazma kaygısı üzerinde olumlu etkisinin olduğu ve yazma kaygısını azalttığı savunulabilir. Koç ve Arslan (2017) tarafından yapılan araştırma bulgularında sınıf düzeyinin öğrencilerin özyeterlik algıları üzerinde anlamlı farklılık oluşturduğu belirlenmiştir. Arslan'ın (2018b) ortaokul düzeyinde yaptığı çalışma incelendiğinde; öğrencilerin sınıf düzeylerinin öz-yeterlik algıları ve yazma kaygıları üzerinde anlamlı farklılık oluşturduğu sonucuna ulaşılmıştır. Aşılıoğlu ve Özkan (2013) tarafından ortaokul düzeyinde yapılan araştırma sonuçlarına bakıldığında sınıf düzeyi değişkeninin öğrencilerin yazma kaygısı üzerinde anlamlı farklılık oluşturduğu görülmektedir. Yedi ve sekizinci sınıf öğrencilerinin dört ve beşinci sınıf öğrencilerine oranla daha düşük yazma kaygısına sahip oldukları tespit edilmiştir. Sınıf düzeyi yükseldikçe yazma kaygısının azaldığı sonucu elde edilmiştir. Bu sonuç öğrencilerin yazmaya ilişkin deneyim ve tecrübe kazandıkça kaygı durumlarında da azalma görüldüğü şeklinde ifade edilebilir. Ateş'in (2013) üniversite düzeyinde yaptığı araştırma sonuçlarında da bu doğrultuda bulgulara ulaşılmıştır. Bir ve ikinci sınıf öğrencilerinin üç ve dördüncü sınıf öğrencilerine kıyasla daha yüksek yazma kaygısı yaşadıkları sonucuna ulaşılmıştır. Yazma kaygısının akademik yaşantıya olan olumsuz etkisi düşünüldügünde eğitimle orantılı olarak azalması istenilen bir sonuç olmaktadır (Zorbaz, 2010).

Öğretim türü değişkenine göre öğrencilerin öz-yeterlik algılarının anlamlı farklılık göstermediği ve puanların birbirine çok yakın görülmektedir. Öğrencilerin yazma kaygılarının da birinci öğretim öğrencilerde daha yüksek olduğu fakat anlamlı farklılık göstermediği belirlenmiştir. Fırat Durdukoca (2010) tarafından üniversite öğrencilerine yönelik yapılan çalışmanın sonuçlarında da öğretim türünün öğrencilerin öz-yeterlik algıları üzerinde etkili olmadığı bulgusuna ulaşılmıştır. 


\section{ULUSLARARASI INTERNATIONAL \\ TÜRK EĞiTiM BILIMLERI DERGISi JOURNAL OF TURKISH EDUCATION SCIENCES \\ UTEB Yı1 /Year: 7 | Sayı / Issue: 12 | Nisan / April 2019 \\ ISSN 2148-2314 $\mid$ uteb.gop.edu.tr}

SHMYO öğrencilerinin gelir düzeyi değişkeni açısından öz-yeterliklerinin ölçeğin yılmama ve sürdürme çabası alt boyutlarında anlamlı farklılık gösterdiği başlama ve toplam puanda ise anlamlı farklılık göstermediği belirlenmiştir. Hangi gruplar arasında anlamlı farklılık olduğunun belirlenmesi için yapılan LSD testi sonuçlarına göre; ölçeğin yılmama alt boyutunda “Çok iyi-Düşük” ve "Orta-Düşük”; sürdürme çabası alt boyutunda "Çok iyi-Düşük”, "İyiDüşük” ve "Orta-Düşük” grupları arasında gelir seviyesini düşük olarak ifade eden grup aleyhine olduğu belirlenmiştir. Toplam puan açısından bakıldığında öz-yeterlik puanlarının gelir düzeyini çok iyi olarak ifade eden öğrencilerde en yüksek düşük olarak ifade eden öğrencilere ise en düşük olduğu görülmektedir. Öğrencilerin yazma kaygılarının gelir düzeyi değişkenine göre anlamlı farklılık gösterdiği ve bu farklılığın "İyi-Orta" grupları arasında iyi lehine olduğu tespit edilmiştir. Yazma kaygısının gelir düzeyini iyi olarak değerlendiren öğrencilerde en düşük, gelir düzeyini düşük olarak değerlendirenlerde ise en yüksek çıktığ saptanmıştır. İkiz ve Yörük'ün (2013) yaptıkları araştırma bulgularında öğrencilerin öz-yeterlik algılarının gelir düzeyi değişkeni açısından anlamlı şekilde farklılaşmadığı bulunmuştur. Yaman (2010) tarafından yapılan çalışmada öğrencinin gelir düzeyinin yazma kaygısı üzerinde belirleyici farklılık oluşturduğu, farklılığın üst gelir düzeyindeki öğrenciler lehine olduğu tespit edilmiştir. İşeri ve Ünal (2012) tarafından üniversite öğrencilerine yönelik yapılan araştırmada öğrencilerin gelir düzeylerinin yazma kaygıları üzerinde belirleyici olmadığı sonucuna ulaşılmıştır. Benzer bir sonuç da Zorbaz (2010) tarafından yapılan çalışmada tespit edilmiştir.

SHMYO öğrencilerinin ikamet yeri değişkeni açısından öz-yeterlik puanlarının ölçeğin alt boyutları ve toplam puanda anlamlı olarak farklılaşmadığı; yazma kaygılarının ise farklılaştığı tespit edilmiştir. Yazma kaygısı puanlarının hangi gruplar arasında farklılaşıtı̆̆ının belirlenmesi amacıyla yapılan LSD testinin sonuçlarına göre "Şehir-Büyükşehir" grupları arasında büyükşehir lehine olmak üzere anlamlı farklılık görülmüştür. İkiz ve Yörük (2013) tarafından yapılan çalışmada elde edilen bulgularda bu çalışmayla uyumlu olarak ikamet yerinin öğrencilerin öz-yeterlik algıları üzerinde anlamlı farklılık oluşturmadığı tespit edilmiştir.

SHMYO öğrencilerinin öz-yeterlik algıları ve yazma kaygılarına ilişkin puanlarının mezun oldukları lise türüne göre anlamlı olarak farklılaşmadığı tespit edilmiştir. Aksu'nun (2008) araştırmasında bu çalışmayla uyumlu olarak mezun olunan lise türünün öğrencilerin öz-yeterlik algıları üzerinde farklılaşmaya neden olmadığı sonucuna ulaşılmıştır. Benzer (2011), Gençtürk ve Memiş (2010) tarafindan yapılan çalışmada da mezun olunan okul türünün öz-yeterlik algısında anlamlı farklılık oluşturmadığı bulunmuştur. Akkuzu ve Akçay (2012) tarafindan öğretmen adaylarına yönelik yapılan araştırma bulgularına bakıldığında mezun olunan lise türünün öğrencilerin öz-yeterlik algıları üzerinde anlamlı farklılık oluşturduğu görülmektedir. Tiryaki'nin (2011) yaptığı araştırmada üniversite öğrencilerinin mezun oldukları lise türünün yazma kaygıları üzerinde anlamlı bir farklılık oluşturmadığı saptanmıştır.

SHMYO öğrencilerinin öz-yeterliklerinin branş değişkenine göre toplam puan ve tüm alt boyutlarda anlamlı olarak farklılık gösterdiği belirlenmiştir. Bu farklılığın hangi gruplar arasında olduğunun belirlenmesi amacıyla yapılan LSD testi sonucuna göre; toplam puanda

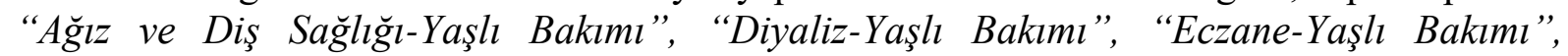
"Odyometri-Yaşlı Bakımı" arasında yaşlı bakımı aleyhine; başlama alt boyutunda "DiyalizYaşlı Bakımı", "Odyometri-Yaşlı Bakımı" arasında yaşlı bakımı aleyhine; yılmama alt

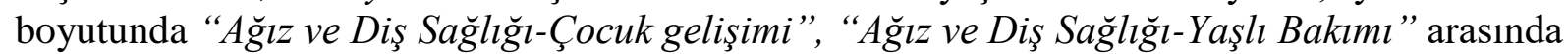
ağız ve diş sağlığı lehine, "Ameliyathane-Yaşlı Bakımı", "Diyaliz-Yaşlı Bakımı" arasında yaşlı bakımı aleyhine; sürdürme çabası alt boyutunda ise "Çocuk Gelişimi-Tıbbi Görüntüleme", "Çocuk Gelişsimi-Yaşlı Bakımı" arasında çocuk gelişimi lehine, "Tıbbi Laboratuvar-Tıbbi 


\section{ULUSLARARASI INTERNATIONAL \\ TÜRK EĞiTiM BiLIMLERI DERGISi JOURNAL OF TURKISH EDUCATION SCIENCES \\ UTEB Y11 / Year: 7 | Sayı / Issue: 12 | Nisan / April 2019 \\ ISSN 2148-2314 $\mid$ uteb.gop.edu.tr}

Görüntüleme”, “Tıbbi Laboratuvar-Yaşlı Bakımı” arasında tıbbi laboratuvar lehine anlamlı farklılığın olduğu tespit edilmiştir. Toplam puana bakıldığında öz-yeterlik algısı en yüksek olan grubun odyometri en düşük olan grubun ise yaşlı bakımı olduğu görülmektedir. Akbaş ve Çelikkaleli (2006) tarafından öğretmen adaylarına yönelik yapılan araştırma bulgularına göre branş değişkeninin öğrencilerin öz-yeterlik algılarında anlamlı farklılık oluşturduğu saptanmıştır. Azar (2012), Gençtürk ve Memiş (2010) tarafından yapılan çalışmada da benzer sonuçlara ulaşılmış ve branş değişkeni açısından öğrencilerin öz-yeterlik algılarında anlamlı farklılık bulunmuştur.

SHMYO öğrencilerinin yazma kaygılarının branş değişkenine göre anlamlı olarak farklılık gösterdiği belirlenmiştir. Bu farklılığın hangi gruplar arasında olduğunun belirlenmesi amaciyla

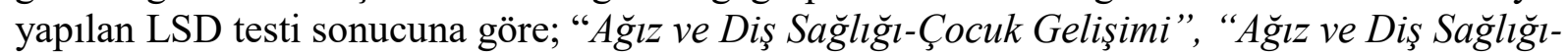

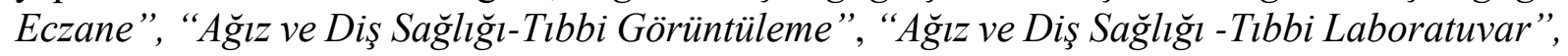
Ağız ve Diş Să̆lı̆̆l-Yaşlı Bakımı" arasında ağız ve diş sağlığı lehine, "Çocuk GelişimiAmeliyathane", "Çocuk Gelişimi-Diyaliz" arasında çocuk gelişimi aleyhine, "Diyaliz-Tıbbi Laboratuvar", "Diyaliz-Yaşlı Bakımı" arasında diyaliz lehine anlamlı farklılığın oluştuğu saptanmıştır. Tiryaki (2011) tarafından üniversite öğrencileri üzerinde yapılan çalışmada öğrencilerin eğitim aldıkları alanın yazma kaygıları üzerinde etkileri olmadığı görülmüştür.

Öğrencilerin yazma kaygısı ölçeğinden aldıkları puan ile öz-yeterlik ölçeğinden aldıkları puanlar arasında negatif yönde bir ilişkinin olduğu görülmektedir. Yazma kaygısı ile öz-yeterlik toplam puanı, başlama ve sürdürme çabası alt boyutu arasında negatif yönde orta düzeyde, yılmama alt boyutu arasında negatif yönde düşük düzeyde bir ilişkinin olduğu tespit edilmiştir. Öğrencilerin öz-yeterlik düzeyleri ile yazma kaygıları arasında negatif yönlü bir ilişkinin tespit edilmiş olması, öz-yeterlikleri arttıkça yazma kaygılarının azalacağı şeklinde yorumlanabilir. Öz-yeterlik inancının olumlu değişkenlerle ilişkisine bakılan çalışmalarda genel olarak pozitif yönde olumsuz değişkenlerle ilişkisine bakılan araştırmalarda ise negatif yönde olduğu görülmektedir. Arslan (2018b) tarafından ortaokul düzeyinde yapılan öğrencilerin yazma kaygıları ve öz-yeterlikleri arasındaki ilişkinin belirlenmesini amaçlayan araştırma bulgularında, yazma kaygıları ile öz-yeterlik algıları arasında orta düzeyde negatif yönde bir ilişkinin olduğu bulunmuştur. Balkıs, Duru ve Buluş (2005) tarafindan yapılan çalışmada öğrencilerin öz-yeterlik algılarının şiddete yönelik tutum ve şiddete yönelik inanç ile negatif yönde bir ilişki gösterdiği görülmektedir. Koç ve Arslan (2017) tarafindan ortaokul öğrencilerine yönelik yapılan araştırma sonuçlarına göre öğrencilerin öz-yeterlik algıları ve okuma stratejileri bilişüstü farkındalıkları arasında orta düzeyde pozitif yönlü bir ilişkinin olduğu saptanmıştır.

Bireyin öz-yeterlik düzeyinin pek çok alanda ortaya koyduğu performans üzerinde olumlu etki gösterdiği alanyazında yapılan çalışmalarla ortaya konulmaktadır. Yazma kaygısının azaltılması üzerinde de olumlu bir etkiye sahip olduğu yapılan bu çalışma, Arslan (2018b), Öztürk ve Saydam (2014) tarafından yapılan çalışmalarla belirlenmiştir. Bu doğrultuda özgüven, motivasyon, özdüzenleme vb. diğer üstbilişsel becerilerin yazma kaygısı üzerindeki etkisini belirlemeye yönelik çalışmaların yapılması gerektiği düşünülmektedir. Yazma becerisinin bireyin kendini ifade etmesinde ve akademik yaşantısında oldukça önemli bir yeri olduğu düşünüldüğünde bu beceriyi olumsuz etkileyen nedenlerin belirlenmesi ve öğretim süreçlerinde mümkün olduğunca çözümlenmeye çalışılması gerekmektedir. Farklı yazma becerilerine ve alternatif öğrenme tekniklerine ağırlık vermenin öğrencinin yazma kaygısı üzerinde olumlu bir etkiye sahip olduğu görülmektedir. Sevim ve Özdemir Erem'in (2013) öğrencilerin yazma kaygıları üzerinde yaratıcı drama etkinliğinin etkisini araştırdıkları 


\section{ULUSLARARASI INTERNATIONAL \\ TÜRK EĞiTiM BíLIMLERI DERGISi JOURNAL OF TURKISH EDUCATION SCIENCES \\ UTEB Y11 / Year: 7 | Sayı / Issue: 12 | Nisan / April 2019 \\ ISSN 2148-2314 $\mid$ uteb.gop.edu.tr}

çalışmada drama etkinliğinin öğrencilerin yazma kaygılarını azalttığı sonucuna ulaşılmıştır. Türkçe dersinde yazma becerisinin temeli atılmakta ve geliştirilmektedir. Öğrenciler bu derste yazma ile ilgili öğrendiklerini diğer derslere aktarmaktadır. Bu nedenle öğrencinin Türkçe ders başarısı yazma kaygısının azaltılmasında önemli olmaktadır. Zorbaz'ın (2010) çalışmasına göre öğrencilerin Türkçe dersindeki başarıları yükseldikçe yazma kaygılarında azalma olduğu tespit edilmiştir. Karakoç Öztürk'ün (2016) öğrencilerin öykü yazma becerilerinin yazma kaygıları üzerindeki etkisinin araştırıldığı çalışmada öğrencilere öykü yazma becerisi kazandırmanın yazma kaygılarını azaltmada olumlu etkiye sahip olduğu tespit edilmiştir. Bu doğrultuda her düzeydeki öğretmene öğrencilerin yazma becerisini geliştirecek ve yazma kaygısını azaltacak etkinlikleri aktif olarak sınıflarda uygulamalarına yönelik bilgi verilmesi gerekmektedir.

\section{KAYNAKÇA}

Akbaş, A. ve Çelikkaleli, Ö. (2006). Sınıf öğretmeni adaylarının fen öğretimi özyeterlik inançlarının cinsiyet, öğrenim türü ve üniversitelerine göre incelenmesi. Mersin Üniversitesi Ĕ̈itim Fakültesi Dergisi, 2(1), 98-110.

Akgün, Ö. E. (2008). Bilgisayar öz-yeterlik algısı. D. Deryakulu (Ed.). Bilişim teknolojileri eğitiminde sosyo-psikolojik değişkenler içinde (ss. 1-32). Ankara: Maya Akademi.

Akgün, F. (2013). Preservice teachers' web pedagogical content knowledge and relationship between teachers' perceptions of self-efficacy. Trakya University Journal of Education, 3(1), 48-58.

Akkuzu, N. ve Akçay, H. (2012). Kimya öğretmen adaylarının öz-yeterlik inançlarının farklı değişkenler açısından incelenmesi (Dokuz Eylül Üniversitesi Örneği). Kuram ve Uygulamada Ë̆itim Bilimleri, 12(3), 2195-2216.

Aksu, H. H. (2008). Öğretmen adaylarının matematik öğretimine yönelik öz-yeterlilik inançlar1. Abant İzzet Baysal Üniversitesi Eğitim Fakültesi Dergisi, 8(2), 161-170.

Akyol, H. (2011). Yeni programa uygun Türkçe öğretim yöntemleri. Ankara: PegemA Akademi Yayınc1lik.

Alamargot, D. ve Chanquoy, L. (2001). Through the models of writing: with commentaries by Ronald T. Kellogg \& John R. Hayes (Vol. 9). London: Kluwer Academic Publishers.

Altıntaş, E. ve Kaya, H. (2012). Fen bilgisi öğretmen adaylarının drama yöntemiyle fen ve teknoloji dersinin işlenmesine yönelik öz-yeterlik ve tutumları. Erciyes Üniversitesi Fen Bilimleri Enstitüsü Fen Bilimleri Dergisi, 28(4), 287-295.

Arslan, A. (2017a). Ortaokul öğrencilerinin okuma kaygıları ve akademik özyeterlik inançlarının çeşitli değişkenler açısından incelenmesi. e-Kafkas Ĕgitim Araştırmaları Dergisi, 4(3), 30-44.

Arslan, A. (2017b). Ortaokul öğrencilerinin dinleme kaygıları ve akademik özyeterlik inançlarının çeşitli değişkenler açısından incelenmesi. International e-Journal of Educational Studies (IEJES), 1(1), 12-31.

Arslan, A. (2018a). Ortaokul öğrencilerinin konuşma kaygıları ve akademik öz-yeterlik inançlarının çeşitli değişkenler açısından incelenmesi. International e-Journal of Educational Studies (IEJES), 2(1), 26-43. DOI: 10.31458/iejes.399014

Arslan, A. (2018b). Ortaokul öğrencilerinin yazma kaygıları ve akademik özyeterlik inançlarının çeşitli değişkenler açısından incelenmesi. Abant İzet Baysal Üniversitesi Eğitim Fakültesi Dergisi, 18(3), 1286-1312.

Aşılığlu, B. ve Özkan, E. (2013). Ortaokul öğrencilerinin yazma kaygılarının bazı değişkenler açısından incelenmesi: Diyarbakır örneği. International Journal of Social Science, 6(6), 83-111.

Aşkar, P. ve Umay, A. (2001). İlköğretim matematik öğretmenliği öğrencilerinin bilgisayarla ilgili öz-yeterlik algısı. Hacettepe Üniversitesi Eğitim Fakültesi Dergisi, 21(21), 1-8. 


\section{ULUSLARARASI INTERNATIONAL \\ TÜRK EĞiTiM BíLIMLERI DERGISi JOURNAL OF TURKISH EDUCATION SCIENCES \\ UTEB Yıl /Year: 7 | Sayı / Issue: 12 | Nisan / April 2019 \\ ISSN 2148-2314 $\mid$ uteb.gop.edu.tr}

Ateş, S. (2013). Foreign language writing anxiety of prospective EFL teachers: how to reduce their anxiety levels. Yayınlanmamış Yüksek Lisans Tezi. Başkent Üniversitesi Eğitim Bilimleri Enstitüsü, Ankara.

Ateş, A. ve Akaydın, Ş. (2015). Ortaokul öğrencilerinin yazma kaygılarının incelenmesi: Malatya ili örneği. Journal of Language and Literature, 15, 24-38.

Azar, A. (2012). Ortaöğretim fen bilimleri ve matematik öğretmeni adaylarının öz yeterlilik inançları. Uluslararası Yönetim İktisat ve Isşletme Dergisi, 6(12), 235-252.

Balkıs, M., Duru, E. ve Buluş, M. (2005). Şiddete yönelik tutumların özyeterlik, medya, şiddete yönelik inanç, arkadaş grubu ve okula bağl1lık duygusu ile ilişkisi. Ege Eğitim Dergisi, 6(2), 81-97.

Bandura, A. (1977). Self-efficacy: toward a unifying theory of behavioral change. Psychological Review, 84(2), 191.

Bandura, A. (1986). Social foundations of thought and action: A social cognitive theory. Prentice-Hall, Englewood Cliffs NJ.

Bandura, A. (1997). Self efficacy: the exercise of control. New York: W. H. Freeman and Company.

Benzer, F. (2011). Illköğretim ve ortaögrretim kurumlarında görev yapan ögretmenlerin öz yeterlik algılarının analizi. Yayınlanmamış Yüksek Lisans Tezi. Selçuk Üniversitesi, Eğitim Bilimleri Enstitüsü, Konya.

Chaplain, R. P. (2000). Beyond exam results? Differences in the social and psychological perceptions of young males and females at school. Educational Studies, 26(2), 177-190

Coşkun, O. (2007). Erzurum'daki sosyal bilgiler öğretmen adaylarının coğrafya alanına yönelik öz yeterlik seviyeleri üzerine bir inceleme. Atatürk Üniversitesi Kâzım Karabekir Ĕ̈itim Fakültesi Dergisi, (15), 201-221.

Cüceloglu, D. (2013). İnsan ve davranışı. (28. Basım). İstanbul: Remzi Kitabevi.

Çeçen, M. A. (2011). Yazma eğitimi açısından metin bilgisi. (Ed: M. Özbay), Yazma eğitimi içinde (s. 127-146). Ankara: Pegem Akademi Yayıncıllk.

Daly, J. (1985). Writing apprehension. when a writer can't write studies in writer's block and other composing process problems. Mike ROSE (Ed). New York: Guilford Press.

Derman, A. (2007). Kimya ögretmeni adaylarının öz yeterlik algllarl ve ögretmenlik mesleğine yönelik tutumları. Yayımlanmamış Doktora Tezi. Selçuk Üniversitesi Fen Bilimleri Enstitüsü, Konya.

Ekici, G. (2005). Biyoloji öz-yeterlik ölçeğinin geçerlik ve güvenirliği. Hacettepe Üniversitesi Ĕ̈itim Fakültesi Dergisi, 29(29), 85-94.

Espin, C. A., Weissenburger, J. W. ve Benson, B. J. (2004). Assessing the writing performance of students in special education. Exceptionality, 12(1), 55-66.

Fırat Durdukoca, Ş. (2010). Sınıf öğretmeni adaylarının akademik özyeterlik algılarının çeşitli değişkenler açısından incelenmesi. Abant İzzet Baysal Üniversitesi Dergisi, 10(1), 69-77.

Gençtürk, A. ve Memiş, A. (2010). İlköğretim okulu öğretmenlerinin öz-yeterlik algıları ve iş doyumlarının demografik faktörler açısından incelenmesi. Illkögretim Online, 9(3), 10371054.

Göçer, A. (2010). Türkçe öğretiminde yazma eğitimi. Uluslararası Sosyal Araştırmalar Dergisi, 3(12), 178-195.

Göğüş, B. (1978). Orta dereceli okullarımızda Türkçe ve yazın eğitimi. Ankara: Gül Yayınevi.

Gülmez, T. (2015). Fen bilgisi ögretmen adaylarının internet özyeterlik düzeyleri ile bilgi okuryazarlık özyeterlikleri arasındaki ilişki. Yayınlanmamış yüksek lisans tezi. Kahramanmaraş Sütçü İmam Üniversitesi Fen Bilimleri Enstitüsü, Kahramanmaraş.

Güneş, F. (2007). Türkçe ögrretimi ve zihinsel yapılandırma. Ankara: Nobel Yayın Dağıtım. 
Hazır Bıkmaz, F. (2004). Özyeterlik inançları. Kuzgun Y. ve Deryakulu, D. (Ed.) Eğitimde bireysel farklılıklar içinde (ss. 289-314). Ankara: Nobel Yayıncılık.

İkiz, F. E. ve Yörük, C. (2013). Öğretmen adaylarının öz-yeterlik düzeyleri ile aile işlevlerinin incelenmesi. Uşak Üniversitesi Sosyal Bilimler Dergisi, 6(1), 228-248.

İşeri, K. ve Ünal, E. (2012). Türkçe öğretmen adaylarının yazma kaygı durumlarının çeşitli değişkenler açısından incelenmesi. Mersin Üniversitesi Eğitim Fakültesi Dergisi, 8(2), 67-76.

Karademir, Ç. A. (2013). Öğretmen adaylarının sorgulama ve eleştirel düşünme becerilerinin ögretmen öz yeterlik düzeyine etkisi. Yayımlanmamış doktora tezi. Adnan Menderes Üniversitesi Sosyal Bilimler Enstitüsü, Aydın.

Karakaya, İ. ve Ülper, H. (2011). Yazma kaygısı ölçeğinin geliştirilmesi ve yazma kaygısının çeşitli değişkenlere göre incelenmesi. Kuram ve Uygulamada Eğitim Bilimleri, 11(2), 691-707.

Karakoç Öztürk, B. (2016). Bir eylem araştırmasının öğrencilerin öykü yazma becerilerine yönelik algılarına ve yazma kaygılarına etkisi. Ana Dili Eğitimi Dergisi, 4(3), 390-415.

Keçik, İ. ve Subaşı Uzun, L. (2004). Türkçe sözlü ve yazılı anlatım. C. İleri (Ed.) Eskişehir: Anadolu Üniversitesi Açıköğretim Fakültesi Yayınları.

Koç, C. ve Arslan, A. (2015). Ortaokul öğrencilerinin başarı yönelimlerinin ve okuma stratejileri bilişüstü farkındalıklarının incelenmesi. Pegem Egitim ve Ögretim Dergisi= Pegem Journal of Education and Instruction, 5(5), 485. DOI: 1.14527/pegegog.2015.027

Maltepe, S. (2006). Yaratıcı yazma yaklaşımı açısından Türkçe derslerindeki yazma süreçlerinin ve ürünlerinin değerlendirilmesi. Yayınlanmamış doktora tezi. Ankara Üniversitesi Sosyal Bilimler Enstitüsü, Ankara.

McLeod, S. (1987). Some thoughts about feelings: The affective domain and the writing process. College Composition and Communication, 38, 426-435.

Melanlığlu, D. (2014). Impact of metacognitive strategies instruction on secondary school students' reading anxieties. Egitim ve Bilim, 39(176), 107-119. DOI: 10.15390/EB.2014.3540

Memiş, A. ve Arıcan, H. (2013). Beşinci sınıf öğrencilerinin matematiksel üstbiliş düzeylerinin cinsiyet ve başarı değişkenleri açısından incelenmesi. Karaelmas Eğitim Bilimleri Dergisi, 1(1), 76-93.

Morgan, C. T. (1998). Psikolojiye giriş. Ankara: Hacettepe Üniversitesi Psikoloji Bölümü Yayınları.

Özbay, M. (2007). Türkçe özel ögrretim yöntemleri II (2. baskl). Ankara: Öncü Kitap ve Yayıncilik.

Özenoğlu Kiremit, H. (2006). Fen bilgisi öğretmenliği ögrencilerinin biyoloji ile ilgili özyeterlik inançlarının karşılaştırılması. Yayınlanmamış doktora tezi. Dokuz Eylül Üniversitesi Eğitim Bilimleri Enstitüsü, İzmir.

Öztürk, G. ve Saydam, D. (2017). Anxiety and self-efficacy in foreign language writing: The case in Turkey. Başkent University Journal of Education, 1(2), 10-21.

Pajares, F. ve Schunk, D. H. (2001). Self-beliefs and school success: Self-efficacy, self-concept, and school achievement. R. Riding ve S. Rayner (Ed.). Selfperception içinde (s. 239-266). London: Ablex Publishing.

Petzel, T. P. ve Wenzel, M. U. (1993). Development and initial evaluation of a measure of writing anxiety. ERIC, 1-13. ED 373072

Poff, I. (2004). Regimentation: a predictor of writer's block and writing apprehension. Yayımlanmamış doktora tezi, University of Southern California (UMI Number: 3155461). 
Schunk, D. H. (2009). Öğrenme teorileri: Eğitimsel bir bakış. (Çev. M. Şahin). Ankara: Nobel Yayın Dağıtım.

Senemoğlu, N. (2005). Gelişim, öğrenme ve öğretim: kuramdan uygulamaya (11. Baskl). Ankara: Gazi Kitabevi.

Sevim, O. ve Özdemir Erem, N. H. (2013). Yaratıcı drama tekniğinin öğrencilerin yazma kaygıları üzerindeki etkileri. Journal of Social Sciences/Sosyal Bilimler Dergisi, 6(11), 975-992.

Sherer, M., Maddux, J. E., Mercandante, B., Prentice-Dunn, S., Jacobs, B. ve Rogers, R. W. (1982). The self-efficacy scale: Construction and validation. Psychological reports, 51(2), 663-671.

Sönmez, V. ve Alacapınar, F. G. (2011). Bilimsel araştırma yöntemleri (1. Baskı). Ankara: Anı Yayıncilik.

Teichman, M. ve Poris, M. (1989). Initial effects of word processing on writing quality and writing anxiety of freshman writers. Computers and the Humanities, 23(2), 93-103.

Tighe, M. A. (1987). Reducing writing apprehension in english classes. ERIC, 1-17. ED 281 196

Tiryaki, E. N. (2011). Üniversite öğrencilerinin tartışmacı metin yazma becerileri ile yazma kaygısı ve eleştirel düşünme becerileri. Yayınlanmamış yüksek lisans tezi. Mustafa Kemal Üniversitesi Sosyal Bilimler Enstitüsü, Hatay.

Tschannen-Moran, M. \& Woolfolk Hoy, A. (2001). Teacher efficacy: capturing an elusive construct. Teaching and Teacher Education, 17, 783-805. DOI: https://doi.org/10.1016/S0742-051X(01)00036-1

Üredi, I. ve Üredi, L. (2006). Sınıf öğretmeni adaylarının cinsiyetlerine, bulundukları sınıflara ve başarı düzeylerine göre fen öğretimine ilişkin öz-yeterlik inançlarının karşılaştırılması. Yeditepe Üniversitesi Eğitim Fakültesi Dergisi, 1(2), 1-8.

Vygostky, L. S. (1998). Düsünce ve dil. B. Erdoğdu (Çev.). İstanbul: Roza Yayınevi.

Warburton, N. (2007). The basics of essay writing. London: Routledge.

Yaman, H. (2010). Writing anxiety of Turkish students: Scale development and the working procedures in terms of various variables. International Online Journal of Educational Sciences, 2(1), 267-289.

Yıldırım, F. ve İlhan, İ. Ö. (2010). Genel öz yeterlilik ölçeği Türkçe formunun geçerlilik ve güvenilirlik çalışması. Türk Psikiyatri Dergisi, 21(4), 301-308.

Zimmerman, B. J. (1995). Self-efficacy and educational development. A. Bandura (Ed.). Selfefficacy in changing societies içinde (s. 202-231). New York: Cambridge University Press.

Zorbaz, K. Z. (2010). İlköğretim okulu öğrencilerinin yazma kaygı ve tutukluğunun yazılı anlatım becerileriyle ilişkisi. Yayınlanmamış doktora tezi. Gazi Üniversitesi Eğitim Bilimleri Enstitüsü, Ankara.

Zorbaz, K. Z. (2011). Yazma kaygısı ve yazma kaygısının ölçülmesi. e-Journal of New World Sciences Academy, 6(3), 2271-2280. 